NBER WORKING PAPER SERIES

\title{
EXPLAINING THE EVOLUTION OF PENSION STRUCTURE AND JOB TENURE
}

Leora Friedberg

Michael Owyang

Working Paper 10714

http://www.nber.org/papers/w10714

\section{NATIONAL BUREAU OF ECONOMIC RESEARCH 1050 Massachusetts Avenue Cambridge, MA 02138}

August 2004

The authors wish to thank Tim Cogley, Wouter den Haan, Douglas Fore, Ruben Hernandez, Rob Dittmar, Alan Gustman, Richard Ippolito, Larry Katz, David Laibson, Trish Pollard, Tara Sinclair and Robert Shimer for helpful comments. Partial funding was provided by TIAA-CREF, the University of Virginia's Bankard Fund for Political Economy, and the Federal Reserve Bank of St. Louis. Abbigail J. Chiodo, Kristie M. Engemann, and Ganesh Seshan provided excellent research assistance. The views in this paper are the authors' alone and do not reflect the views of the Federal Reserve Bank of St. Louis or the Federal Reserve System. The views expressed herein are those of the author(s) and not necessarily those of the National Bureau of Economic Research.

(C)2004 by Leora Friedberg and Michael Owyang. All rights reserved. Short sections of text, not to exceed two paragraphs, may be quoted without explicit permission provided that full credit, including $(\mathrm{C}$ notice, is given to the source. 
Explaining the Evolution of Pension Structure and Job Tenure

Leora Friedberg and Michael Owyang

NBER Working Paper No. 10714

August 2004

JEL No. J32, J63, J65

\section{ABSTRACT}

Current and expected job tenure have fallen significantly over the last two decades. Over the same period, traditional defined benefit pensions, designed to reward long tenure, have become steadily less common. This paper uses a contract-theoretic matching model with moral hazard to explain changes in pension structure and job tenure. In our model, a decline in the value of existing jobs relative to new jobs reduces expected match duration and thus the appeal of DB pensions. We show that this explanation is consistent with observed trends and suggests an additional consequence of technological change that has not been closely studied.

Leora Friedberg

Department of Economics

University of Virginia

P.O. Box 400182

Charlottesville, VA 22904-4182

and NBER

lfriedberg@virginia.edu

Michael Owyang

Research Department

Federal Reserve Bank of St. Louis

411 Locust Street

St. Louis, MO 63102

michael.t.owyang@stls.frb.org 


\section{Introduction}

In the midst of the economic boom of the 1990s, the New York Times suggested that "the notion of lifetime employment has come to seem as dated as soda jerks, or tail fins" (Kolbert and Clymer 1996). ${ }^{1}$ Most data sets show that job tenure, especially of male workers, has fallen over the last two decades. Average tenure of male full-time employees in the Survey of Consumer Finances fell almost 10\%, from 9.7 to 8.8 years, between 1983 and 1998, and expected remaining job tenure dropped more. Average tenure of female full-time employees rose and then fell, suggesting that their rising attachment to the labor force was tempered by an overall decline in tenure. Workers have also experienced a major shift in pension coverage since the early 1980s. Traditional defined benefit pensions, designed to reward long tenure, have become steadily less common, while defined contribution pensions, which are largely portable, have spread.

The link between job tenure and pension trends has not been closely examined, but it offers insights about both phenomena. Analyzing this link allows us to bridge key gaps in the literatures on job stability and on the structure of compensation. First, we develop a matching model with endogenous job destruction that can explain the use of deferred compensation contracts and their connection to job duration. Earlier models of pensions typically did not incorporate uncertainty about job duration, nor make explicit the nature of the worker's outside option - both of which are formulated in matching models and crucially affect the value of tenure-based contracts. Earlier models of job matching rarely incorporated the use of deferred compensation. Recent papers have begun to analyze tenure-based contracts designed to deter on-the-job search $;^{2}$ this paper uses a model with a simpler form of moral hazard to highlight how changes in the economic environment alter the feasibility of such contracts.

Second, we discuss what kinds of shifts in the stochastic productivity process can explain observed trends in job tenure and pension structure. The model does not require a change in the mean productivity of new matches. Instead, we focus on two less drastic possibilities:

\footnotetext{
${ }^{1}$ We have appropriated this quote, with thanks, from Neumark, Polsky, and Hansen (1999).

${ }^{2}$ Burdett and Coles (2003), Stevens (2004), and Friedberg, Owyang, and Sinclair (2003).
} 
(i) an increase in the frequency of shocks that reduce the value of existing matches relative to new matches, or (ii) an increase in uncertainty about future productivity. Thus, the model provides possible explanations for the observed decline in job tenure, while most recent research has focused on documenting recent trends. It also offers a new, endogenous explanation for the decline in DB pensions that differs from the focus of previous research on exogenous changes in pension regulation. The reversal in emphasis here suggests the possibility that regulatory changes responded to an underlying increase in the gains from worker mobility.

Third, we argue that new technologies appear to have reduced the value of existing jobs relative to new jobs and, perhaps, raised uncertainty in the manner in which we hypothesize. We demonstrate that observed patterns of technological change and their relationship to job tenure, and pension structure support the empirical implications of the model.

The paper is organized as follows. In Section 2, we discuss trends in job tenure and pension structure. In Section 3, we review past research on the functions of DB pensions, which may discourage moral hazard, motivate match-specific investment, and deter on-the-job search.

In Section 4, we develop a matching model and incorporate this notion of DB pensions. We show that a contract that defers compensation conditional on tenure, mimicking a DB pension, elicits optimal effort. However, the contract may break down in the face of shocks to the output process which make it riskier to get bound into a long-term relationship.

In Section 5, we present empirical analysis. Because comprehensive data is lacking, we do not estimate our model. Instead, we show that there is a strong empirical relationship between job tenure and pension structure; that the value of long-term jobs appears to have dropped; and that higher rates of technological change in industries are associated with lower job tenure and lower DB pension coverage.

In Section 6, we conclude by linking our results to other research on the nature of new technologies. Many of the phenomena identified in earlier studies support our explanation for a decline in the value of long-term jobs, and our study suggests a further consequence of technological change that has not been closely studied. 


\section{Background}

In this section, we set the stage by presenting trends in job tenure and pension structure and discussing the structure of typical pensions. We also contend that, while pension regulation has changed a great deal, it does not fully explain the observed trends in pension structure.

\subsection{Trends in job tenure}

We find that both current and expected remaining job tenure fell in the Survey of Consumer Finances $(\mathrm{SCF}) .^{3}$ Overall, total expected job duration fell significantly by 10-20\%, depending on the time period and sample. ${ }^{4}$ Our theoretical and empirical analyses later on will draw links between the contemporaneous declines in job tenure and DB pension coverage. ${ }^{5}$

\subsubsection{Current job tenure}

Average job tenure of male full-time employees aged 22-59 in the SCF fell from 9.2 years in 1983 to 8.6 years in 1998. Average tenure of female full-time employees rose from 7.2 years in 1983 to 7.9 years in 1992 and then fell back to 7.2 in 1998. Male job tenure fell across the board by experience and education, and the declines were significant for all but the most experienced workers.

Table 1 shows average job tenure broken down by gender and years of potential experience. Average tenure of men with 0-5 years of potential experience - those least likely to have DB

\footnotetext{
${ }^{3}$ The SCF began in 1983 and surveyed a new cross-section every three years, offering the longest consistent information on pension coverage and job tenure and the only source on expected job tenure. We omit data from 1986, which had an unusual sampling frame. The primary disadvantage is that industry and occupation codes are highly aggregated (only 6-7 categories reported).

${ }^{4}$ Early research did not confirm anecdotal reports of a decline in long-term jobs like the one cited in the introduction (Diebold, Neumark, and Polsky 1997; Farber 1996). Since then, however, researchers have compiled mounting evidence of a decline in male job tenure in most data sets (Neumark, Polsky, and Hansen 1999; BLS 2000; Jaeger and Stevens 1999; Bernhardt, et. al., 1999) except the Survey of Income and Program Participation (Gottschalk and Moffitt 1999). None of these earlier papers used the SCF.

${ }^{5}$ Whether the decline in tenure is dominated by voluntary or involuntary mobility remains unclear. Our model does not yield a meaningful distinction between them since all matches end endogenously. Moreover, it is irrelevant for our primary contention (though not for welfare implications) that trends in job tenure and DB pensions are linked; an increase in either voluntary or involuntary job exits would reduce the value of long-term compensation arrangements.
} 
pensions - declined significantly from 2.8 years in 1983 to 1.7 years in 1998 . Average tenure of those with 6-15 and 16-25 years of potential experience declined significantly from 4.9 to 4.4 years and from 9.9 to 8.6 years, respectively. In results that are not shown, tenure fell for workers who attended college as well as those who did not.

Changes in job tenure among women apparently reflect a combination of increases in labor force attachment early on and secular declines in job tenure later. ${ }^{6}$ Tenure rose and then fell a little for those with 16 or more years of potential experience, while it tended to remain steady early on and then fell more (and statistically significantly) for those with less potential experience.

\subsubsection{Expected job tenure}

The SCF also asked how long respondents expected to continue working for their current employer - yielding a measure of expected job duration that is a key element of the model we present later. Expected tenure is noisier than actual tenure, especially for the smallest group of least experienced workers. Nevertheless, the series show generally significant declines as well, so the drop in current tenure in Table 1 reflects more than a one-time reshuffling of workers into new jobs. Declines are observed across the board by gender and experience over the entire period from 1983 to 1998, and also from 1992 to 1998 when the questions were consistent across years. ${ }^{7}$

Among full-time employees aged 21-59, expected remaining tenure fell significantly for men from 18.0 in 1983 to 15.9 in 1992 and 14.1 in 1998 and for women from 15.3 in 1983 to 13.6 in 1992 and 12.2 in 1998. Table 2 shows expected remaining job tenure by gender and years in the labor market. Among men, expected tenure fell most for those with the least experience. For example, for those with 6-15 years of current tenure, expected remaining tenure fell significantly from 22.6 years in 1983 to 19.6 in 1992 to 16.9 in 1998 . It fell by less for men with current tenure

\footnotetext{
${ }^{6}$ We will focus more on men, as other papers on job tenure tend to. Absent major supply side changes, their trends reveal more about changes rooted in labor demand.

${ }^{7}$ The decline in expected job tenure cannot be attributed to earlier retirement plans. Both the expected retirement age and the proportion who said they would never stop working remained roughly flat over much of the period, and if anything increased in 1998.
} 
of over 15 years of tenure, and their declines between 1992 and 1998 were not significant. Again, changes in expected remaining job tenure among women reflect rising labor supply combined with declining job tenure. For both men and women, expected tenure declined more for the more educated compared to the less educated.

Adding together current and expected remaining tenure yields an estimate of total expected job duration. For men, total expected tenure fell from 27.2 years in 1983 to 24.4 years in 1992 (a decline of 10.1\%) and 22.7 years in 1998 (a further decline of 7.2\%). For women, the total went from 22.5 years in 1983 to 21.5 years in 1992 (a decline of 4.4\%) and 19.3 years in 1998 (a further decline of 10.1\%). Thus, total expected job duration fell significantly by $10-20 \%$, depending on the time period and sample.

\subsection{Pension structure and trends}

At the same time that job tenure declined, DB pensions became steadily less common. Among full-time employees with a pension in the SCF, 69\% had a defined benefit (DB) plan and $45 \%$ had a defined contribution (DC) plan in 1983, while $40 \%$ had a DB plan and $80 \%$ had a DC plan in 1998. Overall pension coverage also declined somewhat, from $67 \%$ of full-time employees in 1983 to $58 \%$ in 1998, suggesting a general move away from deferred compensation. Later, we show that the DB pensions that remain seem to have declined in value as well. In the rest of this subsection, we show how the structure of DB pensions influences tenure, and we discuss changes in pension regulations.

\subsubsection{The structure of pensions}

Defined benefit pensions. DB pensions offer a defined payout to workers after they leave an employer. We can describe its value in terms of pension wealth $P_{t}$, the actuarially discounted real present value of expected future pension benefits if the job ends at year $t$. Pension wealth accrual is the discounted change in pension wealth $\frac{1}{1+r} P_{t+1}-P_{t}$ if the worker stays one additional year and then leaves. 
The path of DB pension wealth accrual is typically characterized by sharp spikes. While the specific parameters of DB plans vary a great deal across employers, Figure 1 shows pension wealth accrual in a particular DB plan in $1992 .{ }^{8}$ Spikes are generated at the vesting date and the early and/or normal retirement dates, depending on the specific pension formula. Large spikes discourage worker mobility for many years after a worker starts a job. Among older workers with a pension in 1992 , median pension wealth was about $\$ 200,000$ if workers stay in their job until age 65. Allen, Clark, and McDermed (1988) estimated that the pension loss associated with switching jobs for the average worker aged 35-54 is approximately half a year's earnings. ${ }^{9}$

Defined contribution pensions. Accumulated employer and mandatory employee contributions to DC plans are a form of deferred compensation. ${ }^{10}$ The accrual of DC pension wealth is simple: contributions go into an account which earns a return, and the account is portable after vesting, which is often immediate (Mitchell 1999). The resulting smooth path of DC pension wealth accrual shown in Figure 1 is largely tenure-neutral and stands in stark contrast to DB accrual. ${ }^{11}$

\subsubsection{Regulation of pension plans}

While employer-provided pensions were largely unregulated for many years, the government has frequently altered and tightened pension regulations since 1974 (Clark and McDermed 1990). Regulatory changes have set funding standards for DB pensions, extended tax incentives for DC pensions, and constrained the structure of pensions in order to, for example, limit how much they

\footnotetext{
${ }^{8}$ Plan data was obtained from employers of respondents in the Health and Retirement Survey and has been slightly altered, as described in Friedberg and Webb (forthcoming), to protect confidentiality.

${ }^{9}$ Gustman and Steinmeier (1993) pointed out that pension wealth may, nevertheless, be quite small at the start of a job. They argued that the primary effect of DB pensions is to deter mobility of longer-tenure, rather than new, workers. When we present our model later, we will discuss extensions involving investment in match-specific capital which capture the importance of mobility incentives of longer-tenure workers.

${ }^{10}$ Employees are typically forbidden from withdrawing or borrowing against their plan balances (Mitchell 1999). Voluntary contributions by employees do not constitute deferred compensation but confer tax benefits that may not be available for other forms of saving. The tax treatment of DB and DC plans is similar, however; contributions are tax-deductible, returns accumulate tax-free, and income is taxable.

${ }^{11}$ Other differences between DB and DC plans do not affect mobility incentives (Friedberg and Owyang 2002a). A recent development is the conversion of traditional DB plans to cash balance plans, hybrids that accrue pension wealth like DC plans but are funded as DB plans. We face little concern about misclassifying cash balance plans in our analysis because they were still uncommon at the end of our SCF sample period in 1998.
} 
can favor high-earning employees. Although researchers have suggested several ways in which these regulatory changes have reduced the appeal of DB pensions, none of them appear to fully explain observed trends in pension structure.

First, as pensions have become increasingly regulated, the costs of administering DB plans increased. However, the cost of administering DC plans rose at similar rates for all but the smallest plans (Ippolito 1995). ${ }^{12}$ Second, Clark and McDermed (1990) claimed that some of the regulatory changes limited the extent to which DB plans can be designed as incentive contracts of the type we model later. ${ }^{13}$ Nevertheless, DB pension wealth can still accrue highly nonlinearly, as in the plan shown in Figure 1. Third, Ippolito (2001, 2003) argued that regulatory changes involving reversion taxes allowed companies to escape their DB pension obligations more easily than before, which undermined the confidence of other workers and motivated the shift to DC pensions. Coronado and Copeland (2003), however, found that only some of the recent conversions which they examined may have been governed by such motives. ${ }^{14}$ Furthermore, a countervailing effect arises from stricter funding standards enacted since 1974, which should increase the willingness of workers to accept DB pensions.

Moreover, a variety of evidence suggests that the evolution of pension structure has been associated with structural shifts in the economy. A series of papers using administrative plan data showed that workers have shifted from jobs that typically offer DB plans to jobs that typically offer DC plans. ${ }^{15}$ In the SCF, we found that pension coverage did not shift uniformly in all jobs but rather at varying rates by industry, occupation, and education level. ${ }^{16}$ Other

\footnotetext{
${ }^{12}$ Kruse (1995) concluded that rising costs might explain some but not all of the decline in DB pensions between 1980 and 1986. Note also that enhanced tax incentives can explain why DC pensions have spread but not why DB pensions have disappeared, since a worker can (and many do) have both types of plans.

${ }^{13}$ Before ERISA established maximum vesting periods, for example, many DB pensions only vested at the normal retirement date.

${ }^{14}$ Only about half of S\&P 500 plans that they identified as converting from DB to cash balance during the 1990s were in a position to be influenced by reversion taxes. Moreover, a majority of the conversions involved increased pension liabilities to existing workers and thus no appropriation of future pension wealth.

${ }^{15}$ Clark and McDermed (1990); Gustman and Steinmeier (1992); Ippolito (1995); Kruse (1995); Papke (1999). According to the second and third papers, for example, the movement of workers across jobs explains half of the shift in aggregate pension structure.

${ }^{16}$ Using analysis-of-variance, year main effects explain just under half $(48 \%)$ of the over-time variation in DB pension coverage - so half of the decline occurred uniformly across types of jobs. Year-industry interactions explain $22 \%$, indicating different changes in DB pension coverage across different industries; year-occupation
} 
papers have shown that changes in pension coverage have mirrored patterns of increasing earnings inequality across skill groups (Bloom and Freeman 1992; Even and Macpherson 2000), another trend which is often attributed to structural changes in the economy.

Various trends in pension characteristics suggest similar factors at work. First, DB pensions are becoming less common in the SCF and DC pensions more common even in unionized and government jobs where pension wealth is difficult to appropriate, in contrast to Ippolito's (2001, 2003) hypothesis. Second, if long-term matches remain valuable, then employers could include tenure-based incentives in DC plans to a greater extent than they do. While around $85 \%$ of DB plans have cliff vesting at the maximum allowed period of five years, less than half of DC plans do. Similarly, employer contributions are based on tenure in only about $10 \%$ of DC profitsharing plans (Mitchell 1999). Lastly, in support of the hypothesis we outline later, Coronado and Copeland (2003) found a significant association between the conversions of DB plans to cash balance plans and the degree of labor mobility in the associated industry.

Thus, numerous pieces of evidence indicate that regulatory changes fail to explain the entire shift in pension structure. Our focus on endogenous explanations provides a complementary perspective and even suggests that regulatory changes may have responsed to an underlying increase in worker mobility.

\section{Theories of DB Pensions}

Past theoretical research analyzes various incentive effects of DB pensions. The model we develop later builds on the idea that DB plans are designed to encourage optimal effort and longer tenure.

DB pensions as incentive contracts. In a series of papers summarized in Lazear (1986), Lazear developed models in which employers structure compensation to deter shirking by workers whose

interactions explain 13\%, and year-education interactions explain $15 \%$. We used survey weights and controlled for age; employer size; union coverage; interactions of occupation with education and industry; and gender and interactions with education, occupation, and industry. Friedberg and Owyang (2002b) described pension trends within industries and occupations. 
effort cannot be observed perfectly. A DB pension motivates effort by workers who do not want to get fired and lose their "bond". ${ }^{17}$ We incorporate this motivation for pensions and define explicitly the nature of uncertainty about job duration and of the worker's outside option - key elements determining the value of tenure-based contracts.

Lazear (1983) argued that DB pensions also function as severance pay to encourage efficient retirement in models with rising wage profiles, another element of an incentive contract. We could extend our model to generate a rising wage profile if we imposed restrictions on the extent to which compensation could be deferred through the DB pension. ${ }^{18}$ We chose not to include an explicit retirement motive, however, since our model generates an endogenous termination date. There is little evidence that a change in retirement motives caused the shift in pension structure, since pensions of older workers have changed much less than pensions of younger and shorter-tenure workers. If anything, the move away from DB plans may have increased firms' use of temporary early retirement inducements (Lumsdaine, Stock, and Wise 1990; Brown 2000).

Other possible motives for DB pensions. An alternative theory is that DB pensions attract more productive workers, rather than eliciting higher productivity after workers are hired (Viscusi 1985; Ippolito 1994). Empirical tests of screening motives for DB pensions have run into difficulties, however, in resolving identification problems (Allen, Clark, and McDermed 1993; Even and Macpherson 1990). Moreover, an endogenous explanation for the shift in pension structure in this class of models involves a decline in the value of screening. This seems implausible given other labor market trends such as the growth in earnings inequality among workers with similar skills, which has been interpreted as an increased return to unobserved ability that should enhance the need to screen workers.

The observed link between unionization and DB pension coverage has led other researchers

\footnotetext{
${ }^{17}$ Related ideas appeared in Becker and Stigler (1974). Similarly, employers may offer DB pensions in order to recoup sunk costs of hiring, firing, or job-specific investments; or to discourage on-the-job search by workers seeking better offers (Burdett and Coles 2003; Friedberg, Owyang, and Sinclair 2003; Stevens 2004).

${ }^{18}$ In Ippolito (1994), wage tilt is necessary when the DB pension is too small to deter a worker from quitting after receiving an attractive outside option. Akerlof and Katz (1989) showed that, in the absence of up-front performance bonds, a rising wage profile is insufficient to deter shirking early in the career; a pension can deter shirking and is often cheaper to the firm than allowing shirking. Ippolito (1991) found, however, that wage tilt had no significant effect on job tenure, while DB pensions did.
} 
to focus on theories of union bargaining. ${ }^{19}$ However, earlier research showed that the decline in unionization does not explain a great deal of the shift in pension structure. Moreover, an implication of the model we develop later is that a decline in a worker's bargaining power has an ambiguous effect. It will make shirking more attractive and thus increase the value of the pension contract, though at the extreme it destroys the pension contract entirely because the contract can no longer deter shirking at all.

Motives for DC pensions. As the use of DB pensions has decreased, why have DC pensions become more popular? Portable DC plans simply constrain the path of consumption, so it is not obvious what explains their use. One possibility is that some DC pensions (though not a large number) replicate incentive effects of $\mathrm{DB}$ pensions through short vesting periods and matching rates. Another possibility is that pensions have an additional purpose as a vehicle for saving, either because individuals have trouble saving on their own or because the government wishes to discourage moral hazard in the presence of social insurance. It is important to note that savings-related motives, which may help explain the use of both DB and DC plans, do not explain the tenure-related structure of DB pensions nor offer an obvious explanation for the shift in pension structure and decline in job tenure.

\section{A Model of Pensions}

We develop an incomplete-contracting job-matching model that incorporates insights about the role of DB pensions. Matching models offer a rich representation of the labor market and of the effects of uncertainty which is absent from earlier models of pensions. Many search and matching models focus on the rate and duration of unemployment and feature exogenous job destruction, while ours emphasizes the duration of employment and endogenous job destruction, which motivates the use of pensions.

We first present a Nash bargaining model with moral hazard which builds on den Haan,

\footnotetext{
${ }^{19}$ Freeman (1985) argued that unions give a stronger voice to older, less mobile workers who use pensions to appropriate rents from younger workers with higher quit rates.
} 
Ramey, and Watson (2000, hereafter DRW). ${ }^{20}$ As in DRW, moral hazard induces endogenous match destruction. We propose a pension-contract model that discourages moral hazard and eliminates inefficient match destruction, although we do not demonstrate that it is the only contract that would do so. After presenting the pension model, we discuss changes in the productivity process that would lead agents to abandon the pension contract.

\subsection{The baseline model with moral hazard}

The following model illustrates the inefficiency generated when unobservable effort on the part of the worker affects future match productivity. While we specify a simple form of moral hazard - low effort today destroys the continuation value of the match - we will indicate how it stands in for a richer model in which a worker decides whether to invest in match-specific capital that keeps the output distribution from drifting down, while skill-specific technological shocks may erode the stock of capital.

The matching market. A continuum of atomistic unemployed workers and firms who are searching in the labor market in a given period meet each other with probability $\lambda .{ }^{21}$ The matched worker and firm $i$ get an output draw $Y_{i, t}$ and decide whether to produce. If they do not produce, they return to the matching market next period. They decide to produce if the output draw exceeds a threshold value $R$, reflecting the surplus from producing today and from the option to get another output draw and produce in future periods.

Production. Output $Y$ is drawn from a distribution $F(y)$ which is the same for all new matches. ${ }^{22}$ Thus, while agents are identical ex ante, matches are heterogeneous in their actual production draws. In each period, agents decide whether to continue producing or rejoin the

\footnotetext{
${ }^{20}$ Valletta (1999) did not write down a model but discussed extensions to a similar model by Ramey and Watson (1997) that could help explain the decline in job tenure. Ramey and Watson modeled bilateral shirking in a pure contract-theoretic framework without search; Valletta discussed the impact of a breakdown in cooperation. Our approach extends the severance contract which Ramey and Watson outlined to the search and matching model employed in DRW.

${ }^{21}$ Friedberg, Owyang, and Sinclair (2003) explore the role of pension contracts when workers search on the job.

${ }^{22}$ At this point, we assume a stationary distribution of $Y$ and suppress the time subscript; later, we discuss the implications of nonstationarity.
} 
labor market and draw their outside options. If the match breaks up, the worker and firm receive $b^{w}$ and $b^{f}$ from their contemporaneous outside option and expect $\phi^{w}$ and $\phi^{f}$ from re-entering the matching pool. If they produce, the agents split the match surplus through Nash bargaining, with shares $\theta$ going to the worker and $1-\theta$ to the firm.

In addition agents are subject to moral hazard; for simplicity, we limit consideration to moral hazard by the worker. A worker who shirks gains $x^{w}$ this period but undermines future match productivity and thus the continuation value $g(R)$. We assume that shirking causes $g(R)$ to go to zero, so the match is severed. ${ }^{23}$

We can define the joint continuation value of the match as

$$
g(R)=\beta \int_{R}^{\infty}(y+g(R)) d F(y)+\beta \int_{0}^{R}(\phi+b) d F(y) .
$$

The continuation value equals the discounted value of the match next period if output exceeds the threshold value $R$, plus the discounted value of the outside option if output falls below $R$.

This allows us to define what the worker and firm gain from re-entering the matching pool as

$$
\begin{gathered}
\phi^{w}=\lambda \beta \int_{R}^{\infty}(\theta(y+g(R)-\phi-b)) d F(y)+\beta\left(\phi^{w}+b^{w}\right) \\
\phi^{f}=\lambda \beta \int_{R}^{\infty}((1-\theta)(y+g(R)-\phi-b)) d F(y)+\beta\left(\phi^{f}+b^{f}\right) .
\end{gathered}
$$

These values depend on the probability of re-matching $\lambda$ and subsequently drawing a satisfactory level of output (exceeding the threshold $R$ ) or alternatively remaining in the matching pool for another period.

Joint surplus from the match is defined as the value of the match less the value of re-entering the matching pool, $Y+g(R)-\phi$, and gets split according to the worker's bargaining share $\theta$. This means that we can define the wage paid to the worker each period as the worker's portion

\footnotetext{
${ }^{23}$ Suppose that match productivity is a function of match-specific human capital which must be kept current at a cost $x^{w}$ to the worker. When the worker fails to update her specific human capital, match productivity falls enough to induce the firm to sever the match.
} 
of the surplus plus his outside option less his portion of the match continuation value. Under Nash bargaining, this is equivalent to the worker's share of output, so $w_{t}=\theta Y_{t}$.

Incentives in the presence of moral hazard. When the agents produce, the value of the match is $Y+g(R)$, current output plus the continuation value. This depends on the threshold output level $R$, which satisfies

$$
R+g(R)=\phi+\max \left\{x^{w}, b\right\},
$$

where $\phi=\phi^{w}+\phi^{f}$ and $b=b^{w}+b^{f}$. At $Y_{t}=R$, agents are just indifferent between continuing or breaking up the match. If the moral hazard premium $x^{w}$ exceeds the outside benefit $b$, then $R$ rises by the difference, as we demonstrate below. The increase in $R$ in the presence of moral hazard raises the expected value of the wage, which compensates the worker for forgoing the moral hazard payment.

We illustrate the impact of moral hazard on sustainable matches in Figure 2. $Y+g(R)$, match output plus the continuation value, appears on the vertical axis; and $\phi+b$, the outside option, appears on the horizontal axis. The Joint Productivity Threshold (Z) shows matches in which the firm's payoff (current period profit $Y-w$ plus continuation value $g^{f}$ ) exceeds its total outside option, while the worker's Incentive Compatibility (IC) constraint shows matches in which the worker's payoff (wage $w$ plus continuation value $g^{w}$ ) exceeds the value of shirking plus the worker's outside option. IC lies a distance of $x^{w}-b$ above $\mathrm{Z}$, since moral hazard imposes an additional requirement on current productivity to sustain the match. Matches below $\mathrm{Z}$ are jointly unproductive and are destroyed. Matches above IC are productive enough that the worker chooses high effort. Matches between IC and Z are broken up (or never formed) because workers choose low effort even though the matches are jointly productive. $x^{w}>b$ creates a wedge between efficient and sustainable matches that require extra productivity in order to overcome shirking.

These scenarios are summarized in the following proposition. 
Proposition 1 Suppose that no steady-state displacements occur in the model without moral hazard (i.e., $Y_{t}+g-\phi-b>0$ ). For any $x^{w}>b$ and nondegenerate $F(y)$ with finite support in the model with moral hazard, the match is incentive compatible and thus is sustained if $w+g^{w}>$ $x^{w}+\phi^{w}+b^{w}$, while the probability of match dissolution due to incentive incompatibility is strictly between zero and one.

The incentive compatibility condition presented in the proposition requires that the worker's payoff (wage $w$ plus continuation value $g^{w}$ ) exceed the value of shirking plus the worker's outside option. The proposition further implies that even though matches are jointly productive, there exists some values of $Y$ for any $x^{w}$ such that the match is not incentive compatible. ${ }^{24}$

An example. Suppose that agents draw productivity $Y$ from a standard uniform distribution. Then, in the solution to (4) that avoids the moral hazard problem, reservation output must satisfy:

$$
R_{M H}=x^{w}+\frac{\beta(1-\lambda)\left(2 b\left(1-R_{M H}\right)-\left(1-R_{M H}^{2}\right)\right)}{2 k} .
$$

where $k=1-\beta(1-\lambda)(1-R){ }^{25}$ If $x^{w}>b$, it drives up the minimum output $R_{M H}$ required to sustain the match, changing the resulting values of $g$ and $\phi . \quad R_{M H}$ exceeds the reservation threshold computed in Nash model without moral hazard,

$$
R_{N}=\frac{2 b-\beta(1-\lambda)\left(1-R_{N}^{2}\right)}{2 k},
$$

since higher productivity is required to deter the worker from shirking and sustain the match. ${ }^{26}$

\footnotetext{
${ }^{24} \mathrm{~A}$ formal proof of a similar proposition appears in DRW. They show that for output below the reservation threshold, the derivative of $R$ with respect to $x$ is strictly positive. Thus, if no steady state dissolutions occur, $x$ can be raised such that $R>0$, so some matches that are dissolved in the MH model would not be dissolved in the $\mathrm{N}$ model.

${ }^{25}$ The solution is obtained by jointly solving the expressions for reservation productivity $R$, the outside option $\phi$, and the continuation value $g$.

${ }^{26}$ To illustrate some comparative statics, a higher value of threshold output $R$ raises the continuation value $g$ but also raises the value $\phi$ of re-entering the matching pool. $R$ itself is a positive concave function of the contemporaneous outside option $b$. Additionally, for high values of $b, R$ increases in the discount rate $\beta$ and decreases in the probability of rematching $\lambda$. Lastly, $R_{M H}>R_{N}$ because $x^{w}>b$ and $0<R<1$.
} 
The impact of moral hazard. Given (4), the worker will shirk if the value of not shirking and sustaining the match (the wage plus continuation value) is smaller than the payoff from shirking (the premium $x^{w}$ and outside option). A higher value of $\theta$, the worker's bargaining power and consequent share of future match rents, reduces the incentive to shirk. A higher $\lambda$, the probability of re-matching, raises the value of the outside option and hence the incentive to shirk. As long as $b<x^{w}$, then a higher $b$, the contemporaneous outside option, increases the reservation threshold $R_{M H}$ but by less than it would increase $R_{N}$. This is because match surplus, and therefore the wage and continuation value, continue to be determined by $b$, but $R$ is now determined in part by $x_{w}$ as well, so $b$ has a reduced effect.

To understand the magnitude of the efficiency loss in response to some of these parameters, we compare aggregate output in a given period $t$ in the moral hazard model, $\tilde{Y}_{M H}=\int_{R_{M H}}^{\infty} d F(y)=$ $1-R_{M H}$, with aggregate output in the Nash model with no moral hazard, $\tilde{Y}_{N}=\int_{R_{N}}^{\infty} d F(y)=$ $1-R_{N}$. The productivity loss resulting from shirking is

$$
\Lambda=\frac{\tilde{Y}_{N}-\tilde{Y}_{M H}}{\tilde{Y}_{N}}=\frac{R_{M H}-R_{N}}{1-R_{N}}
$$

which is always non-negative since $R_{N}<R_{M H}<1$.

Figure 3 plots the productivity loss $\Lambda$, shown on the vertical axis, as the shirk premium $x^{w}$ and the outside option $b$ vary, given other reasonable parameter values $(\lambda=0.3, \beta=0.95$, $\theta=0.5)$. Since output per period lies between 0 and 1 , we analyze values of $x^{w}$ and $b$ of the same order of magnitude. As expected, the productivity loss increases with $x^{w}$ and $b$, since they make shirking more attractive. The productivity loss ranges from 0 to $15 \%$ for $b=0.66$ and $x^{w}$ rising from 0.66 to 0.7 , and it reaches as high as $50 \%$ when $b$ and $x^{w}$ exceed 0.9 .

\subsection{The pension model}

Matches in the moral hazard model are vulnerable to incentives that raise payoffs to the worker today but destroy the future value of the match. This generates inefficient outcomes by forcing 
the dissolution of matches that are jointly productive. Here, we show that a deferred payment conditioned on match tenure - structured like a DB pension - can change the worker's incentives. The contract induces the worker to devote full effort and can be constructed to ensure that the match yields the same positive net productivity as if there were no moral hazard, so matches are efficient.

The pension contract. Suppose that the firm and worker write a contract $\{\bar{w}, W, T\}$ with the following elements:

- The worker collects wage $w=\bar{w}$ in each period when he is working and $t<T$.

- The worker collects $W(T)$, a lump sum, if he is still employed at time $T$.

Without loss of generality, we will set $\bar{w}=0$, and we will discuss the choice of $W$ and its dependence on $T$ later. $^{27}$ We assume that the firm is prevented from breaking up the match if $Y_{t}>R=R_{N}$ and $t<T$ (note that we are focusing on incentive compatible contracts that yield the same jointly productive matches that would arise under Nash bargaining). We also assume that the match breaks up if $Y_{t}<R_{N}$, even if $t<T$. Thus, the firm pays out $W$ at time $T$ as long as $Y_{t}>R_{N}$ each period until $T$. The assumption that firms are prohibited from severing productive matches but allowed to sever unproductive matches rests on the observability of $Y_{t}$ and $R_{N}$. It is crucial, however; if a firm could not break up a match once a contract is in place, the worker would have no incentive not to shirk. Therefore, we must appeal to reputation effects or age discrimination laws which make it more difficult to fire older workers systematically than to lay off workers when output suffers. Along these lines, empirical evidence indicates that obvious breach of deferred compensation contracts by employers is infrequent. ${ }^{28}$

The worker's incentives. Under the pension contract, the worker's continuation value $g_{P}^{w}$ depend on the wage contract $\{\bar{w}, W, T\}$. Again assuming $\bar{w}=0$, then at the outset

\footnotetext{
${ }^{27}$ Enforcement considerations or risk aversion (as in Burdett and Coles 2003) would affect the actual tradeoff between $\bar{w}$ and $W$.

${ }^{28}$ Pontiff, Shleifer, and Weisbach (1990); Cornwell, Dorsey, and Mehrzad (1991); Petersen (1992); Gokhale, Groshen, and Neumark (1995); Coronado and Copeland (2003).
} 


$$
g_{P}^{w}=\beta^{T} W(T)
$$

We need to demonstrate several things about the worker's incentives in order to prove that the pension contract is feasible. First, if the worker accepts the contract in period 1, she will not sever the match later. The continuation value grows in later periods since the value is fixed but the worker discounts it less. Thus, by induction, she will not sever the match in any period $t>1$ unless the productivity distribution shifts (which we have not allowed for yet) such that the worker's outside option grows relatively more valuable.

Next, we summarize in the following proposition both the worker's incentive to shirk after accepting the contract and also the worker's incentive to accept the contract at the outset :

Proposition 2 Suppose that the worker's payoff to shirking is $x^{w}$. Then, the worker will accept the contract $\{\bar{w}, W, T\}$ as long as the shirk premium satisfies $x^{w}<g_{P}^{w}+\bar{w}-\phi^{w}$. Specifically for the case $\bar{w}=0$, if $x^{w}<g_{P}^{w}-\phi^{w}$ in each period, then the worker will choose high effort.

Thus, the worker accepts the contract and does not shirk if the shirk premium is smaller than the value of the contract less the value of the outside option. We can check to see under what circumstances the pension contract satisfies the inequality. Substituting (6) for $g^{w}$ and substituting for the value of $\phi_{N}^{w}$ we solved for above, this requires

$$
x^{w}<\beta^{T-t} W(T)-\theta \beta \frac{b\left(k-\lambda\left(1-R_{N}\right)\right)+\lambda J}{(1-\beta) k}
$$

for all $t=1,2, \ldots, T$. As we mentioned above, the constraint is more to likely bind the lower is t. As time passes, the worker gets closer to the pension payoff and is less likely to shirk and risk getting fired.

Note that condition (7) determines the minimum $W$ necessary to provide the worker with the proper incentives to ensure the match is both incentive compatible and yields joint net positive productivity. The actual choice of $W$ could be modeled as depending on $\theta$, the bargaining weight 
that determines the split of current-period surplus in the Nash model. ${ }^{29}$

Comparative statics. In order to understand how condition (7) governs feasible values of $W$ and $T$, we analyze the impact of the threshold level of output $R_{N}$ and then the fundamental parameters that determine $R_{N}$. (7) identifies the highest sustainable shirk premium $x^{w}$ for a given conditional output $J=\int_{R}^{\infty} y d F(y)=\frac{1}{2}\left(1-R_{N}^{2}\right)$ and severance risk $\pi=\operatorname{Pr}\left[Y_{t}<R_{N}\right]=$ $\int_{0}^{R} d F(y)=R_{N}$. These two quantities are in tension as the reservation threshold $R_{N}$ changes. Higher $R_{N}$ reduces conditional output $J$ and hence the value of re-entering the matching pool by reducing the likelihood that a productive match is formed; this raises the sustainable shirk premium for a given $W$. However, higher $R_{N}$ also raises the severance risk $\pi$, so that staying matched becomes more uncertain; this reduces the sustainable shirk premium. At low $R_{N}$, the effect on $J$ dominates the effect on $\pi$, making the required pension payoff $W$ for a given termination date $T$ relatively insensitive to changes in $R_{N}$. As $R_{N}$ increases, $\pi$ takes over and small changes in the reservation threshold have increasing effect on the sustainability of the pension contract.

Figure 4 shows how the pension payment $W$ that satisfies (7) is affected by some of the model's fundamental parameters. It shows how the minimum $W$, expressed as a percentage of the total expected value of the match at time $T$, changes as the shirk premium $x^{w}$ and the vesting date $T$ change, given other reasonable parameter values $(\lambda=0.3, \beta=0.95, \theta=0.5$, $b=0.5)$. Again, since output per period lies between 0 and 1 , we analyze values of $x^{w}$ of the same order of magnitude.

It is apparent from Figure 4 that the promise of the future pension has a powerful effect in deterring moral hazard. Thus, raising the shirk premium from 0.5 to almost 1 has little effect on the minimum required $W$ for a given $T$. Figure 4 also shows the tradeoff between the term of the pension and its payoff; as noted above, an earlier termination date $T$ allows for a lower

\footnotetext{
${ }^{29} \mathrm{~A}$ possible choice of $W$ is the present value of the Nash bargaining outcome each period, so $W=$ $\sum_{i=1}^{T}\left(\frac{1-R_{N}}{\beta}\right)^{i}\left[\theta y_{t+i \mid t}-\bar{w}\right]$. This is also the expected future discounted value of the match less each period's wage payment, where $R_{N}$ is the severance risk, $y_{t+i \mid t}=E\left[y_{t+i} \mid \Omega_{t}\right]$, and $\Omega_{t}$ is the information available when the contact is written.
} 
payment $W$, given $x^{w}$. If $x^{w}$ is 0.7 , for example, a termination date of 25 periods requires a pension worth at least $27 \%$ of total expected Nash ouput, while a termination date of 15 periods requires a pension worth $10 \%$ of total output.

However, at sufficiently high values of $x^{w}$ (approaching or exceeding 1 , the maximum value of per-period output) the pension contract is no longer viable. The only way to deter shirking is to continue to increase $W$ as $x^{w}$ rises, but this is only profitable if the firm also extends $T$, which raises the risk that the match will be severed before $T$ is reached. At some point governed by (7), the firm cannot offer a high enough $W$ to get the worker to accept the necessary increase in $T$, even if the worker's discount rate $\beta$ gets very close to 1 .

Summary. The contract $\{\bar{w}, W, T\}$ will be accepted by both agents and enhances efficiency when $x^{w}$ satisfies (7). In the next subsection, we discuss how changes in the productivity process affect the pension contract.

\subsection{Expected tenure and the productivity process}

The previous subsection demonstrated how the DB pension (the lump-sum payoff $W$ at time $T$ ) can resolve the inefficiency caused by moral hazard. In the model we laid out above, match productivity does not drift, so the continuation value remains constant. The pension contract will also be effective if productivity drifts upward, boosting the continuation value over time. In this section, we analyze the implications of other possibilities - downward drift that reduces the productivity of existing matches relative to new matches, or an increase in uncertainty. Later on, we discuss the corresponding technology shocks which we have in mind.

We define worker's expected tenure as $E(\tau)=\frac{1}{1-R}$, and we consider changes in the stochastic productivity process that reduce expected job tenure. If the decline is severe enough, it will render the pension contract infeasible, since the worker is no longer willing to defer payment because the risk of exogenous separation becomes too high.

Downward drift in the productivity of existing matches. Consider matches which are initially jointly productive. Suppose now that output each period is drawn from successively less favorable 
probability distributions, so $F_{t+1}(y)>F_{t}(y)$. This implies a time-dependent continuation value in which $g_{t+1}(R)<g_{t}(R)$. The Nash bargaining model then implies an increasing reservation productivity $R_{t+1}>R_{t}$, since conditional output $J>0$ for all $y$; only a higher draw will induce agents to continue the match in the face of worsened long-term prospects. ${ }^{30}$

The resulting condition $R_{t+1}>R_{t}$ has implications for job tenure. The severance risk $\pi=\int_{0}^{R_{t}} d F_{t}(y)$ increases when either the distribution becomes less favorable or reservation output rises. This lowers expected job tenure and thus the expected value of the pension, since the probability that the match lasts until $T$ declines. As we noted in the previous subsection, this effect will reduce the maximum sustainable shirk premium, and at some point the contract breaks down. Put differently, as the likelihood of exogenous separation rises, the payoff date in the contract must get increasingly close to the initiation date for the worker to accept the risk of exogenous separation. However, reducing $T$ also reduces the nominal value $W$ of the pension which the employer is willing to offer. At some point expected tenure $E(\tau)$ becomes small enough that the worker will not accept the contract. Consequently, a decline in expected tenure will reduce the number and value of feasible pension contracts.

Increased uncertainty in the productivity process. The productivity threshold $R$ is unaffected by a change in the variance of the productivity process. Hence, a mean-preserving spread in the productivity distribution raises the probability that the match will fall below the cutoff value $R$ at some future date, if $R$ lies below the mean of the productivity distribution. ${ }^{31}$ Again, the terminal date $T$ must be reduced for workers to accept the pension, but that reduces the payment $W$ which firms are willing to offer, undermining the value of the pension to workers.

Summary. The preceding discussion provides intuition about the breakdown of DB pensions. Contracts that defer payment to the worker preserve jointly efficient matches that would ordinarily be severed in a standard Nash bargaining model. However, shifts in the stochastic process that reduce expected productivity of existing matches make it increasingly unlikely that

\footnotetext{
${ }^{30}$ In the type of human capital model we have alluded to, these shocks can result from the introduction of a new technology which erodes the value of existing skill-specific human capital.

${ }^{31}$ The implications of a mean-preserving spread are reversed if $R$ lies above the mean, but that seems unlikely as it implies that the mean output draw is insufficiently high to warrant forming or preserving a match.
} 
the pension contract can be sustained. A mean-preserving spread in the distribution of future productivity draws that sufficiently augments uncertainty about match duration has a similar effect. $^{32}$

\subsection{Government regulation in the pension model}

While changes in the productivity process may undermine pension contracts, they may also be undone by government regulation. If the government dislikes the outcome that some workers suffer exogenous separation before they collect their pension, it may require that workers be guaranteed their accrued pension wealth if matches end before $T$. This destroys the firm's ability to influence worker effort.

We can evaluate the loss caused by rekindling the moral hazard problem using our earlier definition $\Lambda=\frac{R_{M H}-R_{N}}{1-R_{N}}$ of the efficiency loss arising from moral hazard in the absence of pensions. Figure 3 showed how the efficiency loss $\Lambda$ increases as the shirk premium $x^{w}$ and the outside option $b$ rise, given other reasonable parameter values. For values of $x^{w}$ and $b$ around 0.5 (recall that output draws are bounded between zero and one), the efficiency loss can reach $8 \%$, while for values around 0.65 to 0.7 , it can be twice as high. Thus, our model presents the policymaker with a choice between social efficiency versus improving temporarily the welfare of a fraction of workers who experience bad luck by mandating portability of pensions.

\section{$5 \quad$ Empirical Evidence}

In this section, we present empirical evidence that supports the hypotheses we have presented. It is difficult to estimate our model directly, given the absence of linked employee-employer longitudinal data or even employee longitudinal data with details about the structure of compensation. The alternative is to test implications of the model that relate to pension structure and job

\footnotetext{
${ }^{32}$ One must consider other possible contracts at this point. Ramey and Watson (1997) showed that contracts with severance payments or punishments can sustain matches in the efficient but incentive-incompatible region. However, such contracts are rarely observed, perhaps because they are not easily enforceable or yield socially inefficient litigation.
} 
tenure. There are several types of evidence from the SCF and the CPS that we bring to bear. ${ }^{33}$

First, we show that job tenure is related to pension structure. We find that workers with a DB pension and with more valuable DB pensions have longer tenure than workers with DC pensions or workers with no pensions. Second, we show evidence that the value of long-term jobs - as measured by the value of DB pensions and the "return to tenure" observed in wages - has dropped. This supports our explanation for the decline in job tenure and DB pensions. Third, we present evidence that links technological progress to both the structure of compensation and the decline in long-term jobs. Higher rates of computer use and overall investment across industries are associated with lower rates of DB pension coverage and lower job tenure, and these relationships were more negative in the 1990s than in the 1980s. If, instead, government regulation induced the shift in pension structure, there would be no reason to expect such links.

\subsection{Pension structure and job tenure}

We show that workers with DB pensions have longer current and expected total job tenure than both workers without pensions (as in Allen, Clark, and McDermed 1993) and workers with DC pensions (in contrast to Gustman and Steinmeier 1993). We also find that workers with more valuable DB pensions have longer tenure, controlling for earnings, with the value explaining much of the differential effect on tenure of having a DB pension. However, we do not estimate a structural model of compensation and mobility, so our approach does not distinguish whether DB pensions cause longer tenure. ${ }^{34}$

Regressing job tenure on pension type. We ran several regressions, separately for men and

\footnotetext{
${ }^{33}$ We noted earlier the reasons we concentrate on tenure and pension information from repeated SCFs. We also use tenure information from repeated CPSs, which have larger samples and detailed industry and occupation data, and we use some data from the April $1993 \mathrm{CPS}$, the last time questions were asked about pensions. The notes to each table describe the sample, definition of variables, and estimation details. When using SCF data in this section, all coefficient estimates and standard errors are computed from regressions run on multiple implicates (Rubin 1987).

${ }^{34}$ As noted earlier, we were unconvinced by previous attempts to estimate endogenous selection into DB pensions. While including earnings on the right-hand side in our regressions is just one possible source of endogeneity, it furthers our goal of describing the empirical relationship between tenure and the structure of compensation, while controlling for the level.
} 
women, using both the SCF and the last pension supplement of the CPS. ${ }^{35}$ In the SCF results shown in Table 3, male workers with a DB pension have been in their jobs about 5 years longer than workers without a pension, depending on the specification. Female workers with a DB pension have been in their jobs about 4 years longer. Workers with both a DB and DC pension have been in their job about half a year longer than workers with only a DB pension, but the difference is generally not statistically significant. In comparison, workers with a DC pension have been in their job 2-3 years longer than workers without a pension, significantly shorter than workers with a DB pension. It is unclear a priori whether to control for job characteristics such as industry and occupation which may explain both pension structure and job tenure; including such controls in the second and fourth columns reduces the estimated effect of pensions on tenure by a year or less.

It is important to point out that the relationship between pensions and job tenure does not reflect a spurious correlation between two trending variables, since it remains strong when year effects are included in the third and fourth columns. Moreover, it persists if we interact pension type with year, in results that are not shown. ${ }^{36}$ Since these effects remain strong, we can conclude that the same jobs are experiencing a decline in DB pension coverage and in duration. Without ascribing a structural interpretation, we can understand the magnitude of the estimated effect by noting that the observed decline in DB pension coverage between 1983 and 1998 is associated with a decline in job tenure of 0.9 years for males and 0.6 years for females, according to regressions (4) and (8); this is the same order of magnitude as the observed decline in tenure.

We obtained similar, statistically significant results in additional regressions that are not shown here. We tried using total expected job duration (the sum of current and expected future

\footnotetext{
${ }^{35}$ We run tenure regressions separately because men and women exhibited different secular trends, as noted earlier. If we had such data we could run regressions on the job exit hazard rather than on current tenure, which represents incomplete spells. The mean of complete and incomplete job spells will be the same if spell length is not duration dependent. If it is, then a linear regression on tenure can be viewed as a first-order Taylor expansion of more complicated specifications (Freeman 1980). We obtained similar results from regressions on the log of tenure (Even and Macpherson 1996).

${ }^{36}$ The estimated response to DB pensions remained significantly higher than the response to DC pensions while declining by about 1-2 years by 1998, compared to 1983 .
} 
tenure) as the left-hand side variable. Workers with a DB pension have total expected tenure that is 5.5-7.5 years longer than workers without a pension, while workers with a DC pension have total expected tenure that is 3.5-4.5 years longer. We estimated almost the same effect of pension structure on job tenure in the April 1993 CPS. Moreover, when we replicate the specifications in (2) and (6) of Table 3 with detailed industry and occupation codes, tenure of both male and female workers with a DB pension continues to be about 4 years longer than workers without a pension, versus around 2.5 years for DC pension. ${ }^{37}$

Regressing job tenure on the value of DB pensions. We used SCF data to compute the value of DB pensions and added that information to regressions like those reported in Table 3. In some regressions, we included information which individuals with DB pensions report about the pension benefit which they expect to receive if they stay in their job as long as intended. Because that is endogenous with expected tenure and reported with error, in other regressions we included the average benefit imputed on the basis of earnings, industry, occupation, education, unionization, employer size, and gender. ${ }^{38}$

We find several interesting results, which are shown in Table 4. First, a higher value of one's DB pension at retirement is associated with significantly longer tenure. The semi-elasticity of tenure with respect to the monthly pension benefit (the statistic reported by most of the post1983 sample) is 0.5-0.6 when self-reported information is included (in regressions labeled a) and 0.25-0.4 when the average benefit is included (in regressions labeled b). This implies, for a male with the median value of expected future pension benefits ( $\$ 883$ per month in 1998 dollars), that job tenure is 3.5 years longer than it is for someone without a DB pension, according to (4a); that is half a year longer than someone with the 25 th percentile value (\$351) and almost a year shorter than someone with the 75 th percentile value $(\$ 1867)$. For a female with the median value $(\$ 541)$, job tenure is 3.8 years longer than it is for someone without a DB pension, according to specification $(8 \mathrm{a}) \cdot{ }^{39}$

\footnotetext{
${ }^{37}$ These coefficient estimates are reported in Friedberg and Owyang (2002b).

${ }^{38}$ This is similar to the approach in Gustman and Steimeier (1993), described below, of including an imputed measure of pension backloading.

${ }^{39}$ The numbering of the regressions in Table 4 parallels the numbering of the regressions in Table $3 . \quad$ When we
} 
Second, once we control for DB pension value, then the additional effect of having a DB pension shrinks. It lies in a range between 0.5-3.5 years (versus 4-5 years in Table 3), in some cases not statistically distinguishable from zero and in others not statistically distinguishable from the effect of DC pensions, which remains in the range of 2-3 years. Together, these two findings support our hypothesis that DB pensions are used to extend job tenure, since the differential effect of DB pensions on tenure is operating through the value of the pension.

Third, the semi-elasticity of tenure with respect to earnings is somewhat larger (in the range of 1.5-2.5 years) than the semi-elasticity with respect to pension value. This contradicts results in Gustman and Steinmeier (1993) that they characterized as anomalous. We will discuss their results in greater detail next.

Comparison to other results. The results in the regressions described above, duplicated in two data sets, differ importantly from Gustman and Steinmeier (1993). Unlike us, they found similar mobility rates for workers with DB and DC pensions. Their econometric analysis was similar, but they used the SIPP and included some different variables. The SIPP is a panel, which allowed them to focus on mobility rather than tenure. ${ }^{40}$ However, they only used data from 1984-85, before DC plans became common. Also, in their words, "the SIPP question sequence on plan type is atypical" (p.303) and overstated the prevalence of DC plans. Their results may therefore differ because of the time period or the measurement of job mobility and pension structure.

Another difference was their inclusion of an imputed, selection-adjusted measure of the compensation available in alternative jobs on the right-hand side of their mobility equation. Those results suggested that pensioned workers faced worse alternatives relative to their current job than did non-pensioned workers and that the compensation differential had a greater effect than pension wealth in deterring mobility. This is an important finding, but it hinges on knowing the terms of alternative jobs available to workers who move selectively. No motivation was offered

use total expected tenure on the left-hand side, the estimated semi-elasticities are about twice as large.

${ }^{40}$ The reliability of job mobility data in the SIPP is unclear, since, as we mentioned earlier, it does not show the decline in job tenure which is apparent in other surveys. 
for the identifying exclusion restrictions used in imputing alternative compensation. ${ }^{41}$ Consequently, in our view, the evidence that the alternative compensation premium, rather than the structure of DB pensions, explains the pension-mobility relationship is not convincing. We have reached this conclusion because we find a robust relationship between pension structure and mobility, which contrasts with their estimates even before they controlled for alternative compensation, and because of the difficulties of measuring alternative compensation.

\subsection{The value of long-term jobs to workers}

While we do not have data to estimate changes in the value of a long-term job, we have some evidence about the value to workers. We show two ways in which tenure-related compensation may have shrunk: DB pensions appear to have lost value, and the degree to which earnings rise with tenure has fallen. Balan (2003) also found evidence of the latter using different data.

The value of DB pensions. As described above, from 1989 on the SCF reports the benefit people expect to receive when they leave the firm. In order to detect changes over time, we regress this variable on year dummies. However, the expected pension benefit depends not only on the degree to which a DB pension defers compensation but also on the worker's expected tenure. In order to isolate the first component, we include detailed controls for current and expected remaining job tenure in the regressions. We also control for current earnings, in case overall compensation declined, and in some cases we control for other individual and job characteristics to isolate shifts in the terms of particular jobs, rather than in the composition of jobs.

With the caveat that it may to some extent reflect changes in tenure, the regressions in Table 5 show that DB pensions declined significantly in value between 1989 and 1998. For the average male with a DB pension, according to the results in specification (2), the expected monthly benefit declined by $\$ 46$ between 1989 and 1992, by $\$ 179$ between 1992 and 1995, and by $\$ 69$

\footnotetext{
${ }^{41}$ Age, marital status, children under 18 , and home ownership were included in the mobility equation but excluded from the current and alternative compensation equations.
} 
between 1995 and 1998. The overall drop of $\$ 295$ represented an $18 \%$ decline below the average monthly benefit in 1989 of $\$ 1648$ (measured in 1998 dollars) and is statistically significant at the $90 \%$ confidence level. Among females, according to specification (4), the trend tended to be negative but was not monotonic, since the expected monthly benefit fell $\$ 322$ in 1992 , rose $\$ 256$ in 1995, and then fell $\$ 191$ in 1998 . The overall decline of $\$ 258$, or $26 \%$ below the 1989 value of $\$ 998$, is statistically significant at the $95 \%$ level. These results suggest that DB pensions are smaller than it used to be. ${ }^{42}$

The relationship between tenure and earnings. A common practice in the labor literature is to estimate a "return to tenure", with current earnings on the left-hand side and tenure and other measures of human capital on the right. ${ }^{43}$ If the tenure premium has fallen, it suggests that long-term jobs have become less valuable. Farber (1999) described the problem of interpreting such estimates, since many theories (including ours) predict that compensation is structured to influence tenure. As he argued, such estimates are interesting, nonetheless, in revealing the structure of compensation, and later on we interpret the results in light of ours and other possible models. We used data from CPSs between 1983 and 2000, which offer large sample sizes. ${ }^{44}$ We estimated log earnings equations for men and women separately and included quartics in tenure for each CPS year.

Table 6 shows the earnings premium paid to the average male and female worker with 5,10 , 15,20 , and 25 years of tenure, compared to a worker beginning a job. The results offer some, though not complete, support for our claim that the value of long-term jobs declined. After a mild increase that was not statistically significant in the 1980s, the tenure premium declined sharply, beginning in the early 1990s for men and the middle 1990s for women. For example,

\footnotetext{
${ }^{42}$ We also verified, based on the estimates in Table 5 , that the decline in the value of DB pensions, if it occurred for exogenous reasons, was not nearly large enough to cause the overall decline in job tenure.

${ }^{43}$ While our model does not feature a rising wage profile, we alluded earlier to extensions in which a rising wage is part of an incentive contract to lengthen job duration.

${ }^{44}$ We do not use earlier earlier tenure supplements because the wording changed. We adjusted the reported tenure data for half-year rounding among those with 1-2 years of tenure, though in a simpler way than did Diebold, Neumark, and Polsky (1997). We did not adjust the data for heaping at five-year intervals, as they did; in their 1996 paper, they showed that adjustments for rounding and heaping did not affect conclusions about the magnitude of job tenure trends. When we tried adjusting the sampling weights, as they did, for differences in nonresponse to the tenure question by age, sex, and race, the results were virtually identical.
} 
the earnings premium enjoyed by males with 10 years of tenure rose from $20.4 \%$ in 1983 to $24.7 \%$ in 1991 and then dropped to $16.5 \%$ in 2000. The overall decline between 1983 and 2000 was statistically significant, and it fell the most for males with $10-15$ years of tenure. ${ }^{45}$

For females, the drop-off occurred a little later but was sharper, so that the premium at each year of tenure shown in Table 6 was significantly lower in 2000 than in 1983. For example, for females with 10 years of tenure, the earnings premium rose from $25.5 \%$ in 1983 to $28.5 \%$ in 1996 and then fell to $14.6 \%$ in 2000 .

Balan (2003) also found a decline in the tenure premium that occurred earlier for both men and women in the PSID. Using the panel data to instrument for job tenure, he estimated a significant drop of roughly 3/4 of a percentage point per year between 1981 and 1992 among private-sector non-unionized male workers, with a slightly greater decline for recent job market compared to older workers.

Additionally, we find that the tenure premium dropped in industries with declining tenure, supporting the idea that these trends are linked. We regressed the median real tenure premium on average job tenure in the same industry and found that a one-year decline in average job tenure is associated with a significant 2.7 percentage point decline in the tenure premium (which has a median value of roughly $18 \%) .{ }^{46}$

Interpretation. Our results show that both DB pensions and the earnings premium associated with longer tenure appear to have shrunk in value. What can we infer from this evidence about the value of long-term jobs? We control for the level of current earnings, so these changes are not a consequence of an overall reduction or redistribution of match surplus. In the context of our model, the evidence demonstrates that something related specifically to the duration of the job changed.

\footnotetext{
${ }^{45}$ The F-statistic testing whether tenure was jointly significantly different in 2000 than in 1983 at all of the five-year age intervals shown in Table 6 had a p-value above 97\%. As a point of reference, Topel (1991) estimated that the earnings premium for males with 10 years of tenure was over $25 \%$.

${ }^{46} \mathrm{We}$ computed tenure premia and average job tenure in 45 two-digit industries that employed at least 100 people in each CPS survey. The regressions are weighted by the number of people from the CPS in each cell. If we control for year and industry effects (accounting for economy-wide changes and industry-specific values of the tenure premium), then the correlation is greater, with a one-year decline in average job tenure associated with a 3.7 percentage point decline in the tenure premium.
} 
Our discussion of the pension contract illustrated the tradeoff between the term and the value of the DB pension - as the likelihood of exogenous separation increases, the worker demands a pension that pays off sooner, but the size of the pension that the firm is willing to offer falls and at the limit the viability of pensions is threatened. Thus, a decline in the value of remaining DB pensions supports our hypothesis that the value of long-term jobs fell. If, in contrast, increased regulation explained the shift away from DB pensions, it is not clear why it would also reduce the value of remaining DB pensions.

The literature offers a number of explanations for observing a tenure premium. In the context of those explanations, the inferences we can draw from a declining tenure premium are generally consistent with our main arguments. Obviously, if the tenure premium is a component of a tenure-based incentive contract, then a decline implies that the motivation to use longterm contracts has diminished. Another possible explanation for a tenure premium is selective mobility, so that the observed wage rises with tenure because workers in better jobs stay in them longer. Selective mobility is an outcome of our model - matches end selectively when their productivity draw falls below a reservation level - and it may result in a tenure premium if match productivity drifts upward. A shift in the productivity process that undermines the value of existing relative to new matches would lead to more mobility and an ambiguous effect on the observed tenure premium. A final explanation for observing a tenure premium is that workers are paid their marginal product and match-specific productivity rises with tenure, and a decline in productivity of long-tenured workers causes a decline in the tenure premium. In sum, under various models of wage formation a decline in the tenure premium can be explained by a decline in the productivity of long-term matches.

\subsection{Technological change, pension structure, and job tenure}

We have shown that both actual and expected job tenure fell and that deferred compensation shrank, from which we infer that the value of long-term jobs declined. In our model, this will occur if there is an acceleration of shocks that erode the productivity of existing matches relative 
to new matches, or simply an increase in uncertainty about future productivity. We hypothesize that a shift in the nature of new technologies has had such effects.

As above, and in research by others, there is no data to test directly the effect of new technologies. Instead, we demonstrate that some commonly used measures of technological change are negatively related to both DB pension coverage and job tenure, as we hypothesize. We use data on computer use in jobs, which captures the diffusion of the major new technology of the last 25 years. $^{47}$ We also use data on investment, the capital stock, and total factor productivity (TFP) growth, standard measures of both embodied and neutral technological used in the macroeconomics literature. ${ }^{48}$ We use industry-level data on these measures and match them to industry averages of job tenure and pension structure from the April 1993 CPS (with results shown in Table 7) and with industry averages of job tenure from repeated CPSs (results shown in Table 8). ${ }^{49}$ As above, we include average earnings in the regressions in order to reveal changes in the structure of compensation while controlling for the level.

Technological change and pension structure in industries. The only data source reporting both pension structure and earnings in detailed industries is the April 1993 CPS. We regress average DB pension coverage by industry on measures of technological change and report the results in Table 7. We find that computer use has a negative, sometimes significant relationship with DB pension coverage, and that TFP growth, investment, and capital have significant negative relationships. Based on the most detailed specification in column (3), an industry with a one standard deviation higher rate of computer use has a 3.7 percentage point lower rate of DB pension coverage, which amounts to $7.6 \%$ of the mean. ${ }^{50}$ Based on the specification in (4), an

\footnotetext{
${ }^{47}$ In October 1984, 1989, 1993, 1997, and September 2001, the CPS asked individuals whether they used a computer at work. We compute average computer use in 50 industries in each CPS. In 2001, we also count as computer users those who reported that they had a home computer and used it for work.

${ }^{48}$ We use investment, capital, and TFP data from the Jorgenson Total Factor Productivity Series, which covers 21 disaggregated manufacturing sectors and 14 not-so-disaggregated non-manufacturing sectors annually from 1959 to 1996 . While we average the data over 10-year periods, we obtained generally similar estimates using averages over 5 years.

${ }^{49}$ These were among the measures used by Autor, Katz, and Krueger (1998) and Bartel and Sicherman (1999) to determine the impact of technological change on workers. We did not think it useful to try to match the measures of technological change to SCF data, since SCF industry codes are so highly aggregated.

${ }^{50}$ Computer use is significant in (3), when measures of past and future changes in computer use are also included, though they are highly insignificant. In all specifications, we control for log average earnings and average health
} 
industry with a one standard deviation higher rate of TFP growth (investment) has a 3.7 (3.3) percentage point lower rate of DB pension coverage. ${ }^{51}$ The magnitudes of these relationships are quite similar across all the measures of technological change.

Technological change and job tenure in industries. Table 7 also reports the relationship between job tenure in the April 1993 CPS and measures of technological change. Computer use, investment, and the capital stock all have a significant negative relationship with job tenure. Based on any of the specifications in (6)-(8), a one standard deviation higher rate of computer use is associated with about 0.75 years less in average job tenure, or $9 \%$ of the overall average. ${ }^{52}$ Based on the specification in (9), a one standard deviation higher level of investment is associated with about 0.5 years less in average job tenure. ${ }^{53}$

We also use repeated CPS job tenure supplements to explore the relationship over time with these measures of technological change, as shown in Table 8. Computer use has a negative, significant relationship with job tenure in specifications (1) and (3); however, it shrinks a little and loses significance when controlling for year effects in job tenure in (2) and (4), and the estimate is smaller than it was in the April 1993 regressions. Investment and the capital stock also have a negative and significant association with job tenure in (7) and (9); the coefficients only decline slightly when year effects are included in (8) and (10), and they remain a little larger than the estimate in the April 1993 regressions.

While the evidence is weaker when we include year effects, we find that these relationships strengthened over time. All the relevant coefficients are smaller and/or more negative when we include year effects but limit the time period to the 1990s. Comparing (5) and (6), computer use has a negative but insignificant relationship with job tenure before 1990 and a more negative and now significant relationship after 1990. Similarly comparing (11) and (12), the relationship between investment and job tenure becomes more negative and significant after 1990, while the

insurance coverage (as measures of the level of compensation) and weight the regression by the number of workers in each industry (so that the results reflect economywide averages).

${ }^{51}$ When investment and the capital stock are both included, they are jointly but not individually significant. We obtain similar results when we replace the level of investment with the investment-capital ratio.

${ }^{52}$ Past or fugure changes in computer use do not have additional effects on job tenure.

${ }^{53} \mathrm{TFP}$ growth has a positive but highly insignficant relationship with job tenure. 
positive effect of TFP growth on job tenure disappears.

Summary. We find a consistent negative relationship between measures of technological change and industry-level averages of DB pension coverage and job tenure. As far as we know, results like these have not appeared in past research, and they support our claim that the nature of new technologies has changed in ways that undermines the value of long-term jobs.

\section{Conclusion}

In this paper we have specified a model of DB pensions and job tenure. DB pensions eliminate inefficient job destruction resulting from moral hazard; in more complex models, the moral hazard can take the form of searching on-the-job or failing to invest in job-specific capital. The use of DB pensions is undermined, however, if expected job tenure declines. We have shown in this paper that both actual and expected job tenure have fallen along with the use of DB pensions.

We also used the model to demonstrate the types of changes in the stochastic productivity process which reduce expected job tenure and hence the use of DB pensions. We focused on shocks that increase uncertainty about future match productivity and showed, moreover, that industries with more rapid rates of technological change have also experienced greater declines in job tenure.

These results complement a large body of research analyzing the shifting nature and pace of technological changes. Much of this research suggests that they have had the effects on jobs that we have in mind. The diffusion of new, especially information-related, technologies appears to have had a powerful effect on the level of compensation, raising earnings inequality along a variety of dimensions (Gottschalk 1997, Acemoglu 2002). Inequality in pension and health insurance coverage has jumped over the same period.

The key reason for rising inequality, according to this literature, is that new technologies are largely skill and ability-biased (Autor, Katz, and Krueger 1998). Case study evidence suggests that new technologies require not just greater but also new skills. Computer use is, obviously, one 
of the new skills; employers and individuals continue to devote substantial resources to computer training, even while computers have grown easier to use over time. ${ }^{54}$ Besides that, computers have automated routine tasks while altering and often making more complex the performance of non-routine tasks (Levy and Murnane 1996, Autor, Levy, and Murnane 2002). Computerization has brought on further changes in required skills, workplace organization, and the delivery of services (Bresnahan, Brynjolffson, and Hitt 2002).

Our results add to this literature by suggesting additional consequences of the diffusion of new technologies. We find evidence that jobs have been reorganized in ways that loosen the ties of long-term relationships between workers and firms.

\section{References}

[1] Acemoglu, Daron. "Technical Change, Inequality, and the Labor Market." Journal of Economic Literature, March 2002, 40(1), pp. 7-72.

[2] Akerlof, George A., and Katz, Lawrence F. "Workers' Trust Funds and the Logic of Wage Profiles." Quarterly Journal of Economics, August 1989, 104(3), pp. 525-536.

[3] Allen, Steven G.; Clark, Robert L., and McDermed, Ann A. "Pensions, Bonding, and Lifetime Jobs." Journal of Human Resources, Summer 1993, 28(3), pp. 463-481.

[4] Allen, Steven G.; Clark, Robert L., and McDermed, Ann A. "The Pension Cost of Changing Jobs." Research on Aging, December 1988, 10(4), pp. 459-471.

[5] Autor, David H.; Katz, Lawrence F., and Krueger, Alan B. "Computing Inequality: Have Computers Changed the Labor Market?" Quarterly Journal of Economics, November 1998, 113(4), pp. 1169-1213.

\footnotetext{
${ }^{54}$ For example, the University of Virginia provided computer training to 2000-3000 staff in over two thousand total workshops per year during 1998-2001, furnishing 3.86 training hours per employee in 2001, up from 0.73 in 1994 (Friedberg 2003).
} 
[6] Autor, David H.; Levy, Frank, and Murnane, Richard J. "Upstairs, Downstairs: Computers and Skills on Two Floors of a Large Bank." Industrial and Labor Relations Review, April 2002, 55(3), pp. 432-447.

[7] Balan, David. "Have Lazear-Style Implicit Contracts Disappeared?" Manuscript, Federal Trade Commission, January 2003.

[8] Bartel, Ann, and Sicherman, Nachum. "Technological Change and Wages: An InterIndustry Analysis." Journal of Political Economy, 1999, 107(2), pp. 285-325.

[9] Becker, Gary S., and Stigler, George J. "Law Enforcement, Malfeasance, and Compensation of Enforcers." Journal of Legal Studies, 1974, 3(1), pp. 1-18.

[10] Bernhardt, Annette; Morris, Martina; Handcock, Mark S., and Scott, Marc A. "Trends in Job Instability and Wages for Young Adult Men." Journal of Labor Economics, October 1999, 17(4) Part 2, pp. S65-S90.

[11] Bloom, David E., and Freeman, Richard B. "The Fall in Private Pension Coverage in the United States." American Economic Review Papers and Proceedings, May 1992, 82(2), pp. $539-545$.

[12] Bresnahan, Timothy F.; Brynjolfsson, Erik, and Hitt, Loren M. "Information Technology, Workplace Organization, and the Demand for Skilled Labor: Firm-Level Evidence." Quarterly Journal of Economics, February 2002, 117(1), pp. 339-376.

[13] Brown, Charles. "Early Retirement Windows." In Mitchell, Olivia S.; Hammond, P. Brett, and Rappaport, Anna M., eds., Forecasting Retirement Needs and Retirement Wealth. Philadelphia: University of Pennsylvania Press, 2000.

[14] Burdett, Ken, and Coles, Melvyn. "Equilibrium Wage-Tenure Contracts." Econometrica, September 2003, 71(5), pp. 1377-1404. 
[15] Bureau of Labor Statistics. "Employee Tenure in 2000." Press report, U.S. Department of Labor, August 29, 2000.

[16] Clark, Robert L., and McDermed, Ann A. The Choice of Pension Plans in a Changing Regulatory Environment. AEI Studies, No. 509, Washington, D.C.: AEI Press, 1990.

[17] Cornwell, Christopher; Dorsey, Stuart, and Mehrzad, Nasser. "Opportunistic Behavior by Firms in Implicit Pension Contracts." Journal of Human Resources, Fall 1991, 26(4), pp. 704-725.

[18] Coronado, Julia, and Phillip Copeland. "Cash Balance Pension Plan Conversions and the New Economy." Manuscript, Federal Reserve Board of Governors.

[19] den Haan, Wouter; Ramey, Garey, and Watson, Joel. "Job Destruction and the Experiences of Displaced Workers." Carnegie-Rochester Conference Series on Public Policy, June 2000, 52(0), pp. 87-128.

[20] Diebold, Francis X.; Neumark, David, and Polsky, Daniel. "Job Stability in the United States." Journal of Labor Economics, April 1997, 15(2), pp. 206-233.

[21] Even, William E., and Macpherson, David A. "The Gender Gap in Pensions and Wages." Review of Economics and Statistics, May 1990, 72(2), pp. 259-265.

[22] Even, William E., and Macpherson, David A. "Employer Size and Labor Turnover: The Role of Pensions." Industrial and Labor Relations Review, July 1996, 49(4), pp. 707-728.

[23] Even, William E., and Macpherson, David A. "The Changing Distribution of Pension Coverage." Industrial Relations, April 2000, 39(2), pp. 199-227.

[24] Farber, Henry S. "Are Lifetime Jobs Disappearing? Job Duration in the United States: 1973-1993." In Haltiwanger, John, Manser, Marilyn E., and Topel, Robert H., eds., Labor Statistics Measurement Issues. Chicago: University of Chicago Press, 1996. 
[25] Farber, Henry S. "Mobility and Stability: The Dynamics of Job Change in Labor Markets." In Ashenfelter, Orley, and Card, David, eds., Handbook of Labor Economics, Volume 3A. Amsterdam: Elsevier Science, 1999.

[26] Freeman, Richard B. "The Exit-Voice Tradeoff in the Labor Market: Unionism, Job Tenure, Quits, and Separations." Quarterly Journal of Economics, June 1980, 94(4), pp. 643-673.

[27] Freeman, Richard B. "Unions, Pensions, and Union Pension Funds." In Wise, David A., ed., Pensions, Labor, and Individual Choice. Chicago: University of Chicago Press, 1985, pp. $89-118$.

[28] Friedberg, Leora. "The Impact of Technological Change on Older Workers: Evidence from Data on Computer Use." Industrial and Labor Relations Review, April 2003, 56(3), pp. $511-529$.

[29] Friedberg, Leora, and Owyang, Michael T. "Not Your Father's Pension Plan: The Rise of 401(k) and Other Defined Contribution Plans." Federal Reserve Bank of St. Louis Review, January-February 2002, 84(1), pp. 23-34.

[30] Friedberg, Leora, and Owyang, Michael T. "Explaining the Evolution of Pension Structure and Job Tenure." Working Paper No. 2002-022B, Federal Reserve Bank of St. Louis, October 2002.

[31] Friedberg, Leora; Owyang, Michael T., and Sinclair, Tara M. "Searching For Better Prospects: Endogenizing Falling Job Tenure and Private Pension Coverage.” Working Paper 2003-038A, Federal Reserve Bank of St. Louis, November 2003.

[32] Friedberg, Leora, and Webb, Anthony. "Retirement and the Evolution of Pension Structure." Journal of Human Resources, forthcoming. 
[33] Gokhale, Jagadeesh; Groshen, Erica L., and Neumark, David. "Do Hostile Takeovers Reduce Extramarginal Wage Payments?" Review of Economics and Statistics, August 1995, 77(3), pp. $470-485$.

[34] Gottschalk, Peter. "Inequality, Income Growth, and Mobility: The Basic Facts." Journal of Economic Perspectives, Spring 1997, 11(2), pp. 21-40.

[35] Gottschalk, Peter, and Moffitt, Robert. "Changes in Job Instability and Insecurity Using Monthly Survey Data." Journal of Labor Economics, October 1999, 17(4) Part 2, pp. S91-S126.

[36] Gustman, Alan L., and Steinmeier, Thomas L. "The Stampede Toward Defined Contribution Pension Plans: Fact or Fiction?" Industrial Relations, Spring 1992, 31(2), pp. 361-369.

[37] Gustman, Alan L., and Steinmeier, Thomas L. "Pension Portability and Labor Mobility: Evidence from the Survey of Income and Program Participation." Journal of Public Economics, March 1993, 50(3), pp. 299-323.

[38] Ippolito, Richard A. "Encouraging Long-term Tenure: Wage Tilt or Pensions?" Industrial and Labor Relations Review, April 1991, 44(3), pp. 520-535.

[39] Ippolito, Richard A. "Pensions and Indenture Premia." Journal of Human Resources, Summer 1994, 29(3), pp. 795-812.

[40] Ippolito, Richard A. "Toward Explaining the Growth of Defined Contribution Pensions." Industrial Relations, January 1995, 34(1), pp. 1-20.

[41] Ippolito, Richard A. "Reversion Taxes, Contingent Benefits, and the Decline in Pension Funding." Journal of Law and Economics, April 2001, 44(1), pp. 199-232.

[42] Ippolito, Richard A. "Tenuous Property Rights: The Unraveling of Defined Benefit Pension Contracts in the United States." In Onorato Castellino and Elsa Fornero, eds., Pension Policy in an Integrating Europe. Northhampton, Mass.: Edward Elgar Publishing, 2003. 
[43] Jaeger, David A., and Stevens, Ann Huff. "Is Job Stability in the United States Falling? Reconciling Trends in the Current Population Survey and Panel Study of Income Dynamics." Journal of Labor Economics, October 1999, 17(4) Part 2, pp. S1-S28.

[44] Jorgenson, Dale W.; Gollop, Frank M., and Fraumeni, Barbara M. Productivity and U.S. Economic Growth. Cambridge, MA: Harvard University Press, 1987.

[45] Kolbert, Elizabeth, and Clymer, Adam. "The Politics of Layoffs: In Search of a Message." New York Times, March 8, 1996, p.A23.

[46] Kruse, Douglas L. "Pension Substitution in the 1980s: Why the Shift toward Defined Contribution?" Industrial Relations, April 1995, 34(2), pp. 218-241.

[47] Lazear, Edward P. "Pensions As Severance Pay." In Bodie, Zvi, and Shoven, John B., eds., Financial Aspects of the United States Pension System. Chicago: University of Chicago Press, 1983.

[48] Lazear, Edward P. "Retirement from the Labor Force." In Ashenfelter, Orley, and Layard, Richard, eds., Handbook of Labor Economics, Volume 1. New York: Elsevier Science Publishers, 1986.

[49] Levy, Frank, and Murnane, Richard J. "With What Skills are Computers a Complement?" American Economic Review Papers and Proceedings, May 1996, 86(2), pp. 258-262.

[50] Lumsdaine, Robin L.; Stock, James H., and Wise, David A. "Efficient Windows and Labor Force Reduction." Journal of Public Economics, November 1990, 43(2), pp. 131-159.

[51] Mitchell, Olivia S. "New Trends in Pension Benefit and Retirement Provisions." Working Paper No. w7381, National Bureau of Economic Research, October 1999.

[52] Neumark, David; Polsky, Daniel, and Hansen, Daniel. "Has Job Stability Declined Yet? New Evidence for the 1990s." Journal of Labor Economics, October 1999, 17(4) Part 2, pp. S29-S64. 
[53] Papke, Leslie E. "Are 401(k) Plans Replacing Other Employer-provided Pensions? Evidence from Panel Data." Journal of Human Resources, Spring 1999, 34(2), pp. 346-368.

[54] Petersen, Mitchell A. "Pension Reversions and Worker-Stockholder Wealth Transfers." Quarterly Journal of Economics, August 1992, 107(3), pp. 1033-1056.

[55] Pontiff, Jeffrey; Shleifer, Andrei, and Weisbach, Michael S. "Reversions of Excess Pension Assets after Takeovers." RAND Journal of Economics, Winter 1990, 21(4), pp. 600-613.

[56] Ramey, Garey, and Watson, Joel. "Contractual Fragility, Job Destruction, and Business Cycles." Quarterly Journal of Economics, August 1997, 112(3), pp. 873-911.

[57] Rubin, Donald B. Multiple Imputation for Nonresponse in Surveys. New York: John Wiley \& Sons, 1987.

[58] Stevens, Margaret. "Wage-Tenure Contracts in a Frictional Labour Market: Firms' Strategies for Recruitment and Retention." Review of Economic Studies, April 2004, 71(2), pp. $535-551$.

[59] Topel, Robert. "Specific Capital, Mobility, and Wages: Wages Rise with Job Seniority." Journal of Political Economy, February 1991, 99(1), pp. 145-176.

[60] Valletta, Robert G. "Declining Job Security." Journal of Labor Economics, October 1999, 17(4) Part 2, pp. S170-S197.

[61] Viscusi, W. Kip. "The Structure of Uncertainty and the Use of Nontransferable Pensions as a Mobility-Reduction Device." In Wise, David A., ed., Pensions, Labor, and Individual Choice. Chicago: University of Chicago Press, 1985, pp. 223-248. 
Table 1: Current job tenure

\begin{tabular}{lcccccccc}
\hline & \multicolumn{4}{c}{ Men } & \multicolumn{6}{c}{ Women } \\
& \multicolumn{4}{c}{ Average, by years of potential experience } \\
1983 & $0-5$ & $6-15$ & $16-25$ & $26-35$ & $0-5$ & $6-15$ & $16-25$ & $26-35$ \\
\cline { 2 - 9 } 1989 & 2.8 & 4.9 & 9.9 & 14.2 & 2.3 & 4.9 & 7.7 & 9.9 \\
1992 & 2.2 & 4.8 & 8.9 & 14.7 & 1.9 & 4.0 & 7.6 & 10.5 \\
1995 & 2.3 & 4.8 & 8.1 & 14.1 & 2.1 & 4.8 & 8.2 & 11.8 \\
1998 & 2.0 & 4.6 & 8.5 & 12.9 & 2.1 & 4.4 & 8.4 & 10.7 \\
change 1998-83 & 1.7 & 4.4 & 8.6 & 13.6 & 1.7 & 4.0 & 7.4 & 11.1 \\
(standard error) & -1.1 & -0.6 & -1.4 & -0.7 & -0.6 & -0.8 & -0.3 & 1.2 \\
& $(0.2)$ & $(0.3)$ & $(0.5)$ & $(0.8)$ & $(0.2)$ & $(0.3)$ & $(0.5)$ & $(0.8)$ \\
\hline
\end{tabular}

Data source: Survey of Consumer Finances from 1983, 89, 92, 95, 98. Respondents were asked "How many years in total have you worked for this employer?”

Sample: Full-time employees aged 22-59, except those who reported tenure that exceeded potential experience plus two years (about $1.5 \%$ of the sample).

Details: Means and standard errors are computed from multiple implicates (Rubin 1987), using survey weights. Years of potential experience is defined as age minus years of completed education minus six.

Table 2: Expected remaining job tenure

\begin{tabular}{lcccccccc}
\hline & \multicolumn{9}{c}{ Men } & \multicolumn{7}{c}{ Women } \\
& \multicolumn{9}{c}{ Average, by years of potential experience } \\
1983 & $0-5$ & $6-15$ & $16-25$ & $26-35$ & $0-5$ & $6-15$ & $16-25$ & $26-35$ \\
\cline { 2 - 9 } 1989 & 18.3 & 21.8 & 20.2 & 13.2 & 15.3 & 18.3 & 17.9 & 11.4 \\
1992 & 11.0 & 18.4 & 17.8 & 11.6 & 8.7 & 13.2 & 14.6 & 9.8 \\
1995 & 16.7 & 18.7 & 17.5 & 11.9 & 13.6 & 15.8 & 14.9 & 10.9 \\
1998 & 11.1 & 17.3 & 16.3 & 11.4 & 8.7 & 15.4 & 13.6 & 10.2 \\
change 1998-83 & 10.6 & 16.1 & 16.3 & 11.0 & 10.1 & 13.0 & 14.7 & 10.4 \\
(standard error) & -7.7 & -5.7 & -3.9 & -2.2 & -5.1 & -5.3 & -3.2 & -1.0 \\
change 1998-92 & $(2.4)$ & $(1.1)$ & $(0.8)$ & $(0.6)$ & $(2.4)$ & $(1.2)$ & $(0.9)$ & $(0.8)$ \\
(standard error) & $(2.9)$ & -2.6 & -1.2 & -0.9 & -3.5 & -2.9 & -0.2 & -0.5 \\
& $(1.5)$ & $(1.2)$ & $(0.7)$ & $(5.5)$ & $(1.9)$ & $(1.3)$ & $(0.9)$ \\
\hline
\end{tabular}

Data source: Survey of Consumer Finances from 1983, 89, 92, 95, 98. Respondents were asked "How many years do you expect to continue working for this employer?”

Sample: Same as in Table 1.

Details: Means and standard errors are computed from multiple implicates, as in Rubin (1987), using survey weights. Years of potential experience is defined as age minus years of completed education minus six.

Approximately $14 \%$ of respondents answered that they would "never stop"; we imputed a specific answer for them as follows: (1) we used their answer if they responded to a later question about when they would retire from all work; or else (2) we used their answer if they responded to a later question about when they would retire from full-time work; or else (3) we assumed that they would work until the age of seventy.

In 1995-98, "less than a year" was coded as a separate answer, in which case we assigned a value of zero; in 1983-92 one is the smallest coded response, and for respondents who were coded with a value of one, we randomly assigned an answer of zero in the same proportion as is observed among those answering zero or one in 1995-98 (which will lead to a slight underestimate of the decline in tenure). 
Table 3: Job tenure and pension coverage (OLS regression results, SCF)

Dependent variable: years of current job tenure

Men (mean of dependent variable $=8.77$ )

(1)

(2)

(3)

(4)

Independent variables:

has DB pension only

has DC pension only

$5.49^{* * *}(0.27)$
$2.54^{* * *}(0.28)$
$5.69^{* * *}(0.35)$

$4.24^{* * *}(0.29)$

$5.47^{* * *}(0.28)$

$2.55^{* * *}(0.28)$

$4.44^{* * *}(0.30)$

has DB \& DC pension

$5.00^{* * *}(0.34)$

$5.66^{* * *}(0.35)$

$2.31^{* * *}(0.28)$

$5.05^{* * *}(0.35)$

Women (mean of dependent variable $=7.62$ )

(5)

(6)

(7)

(8)

Independent variables:

$\begin{array}{lllll}\text { has DB pension only } & 4.07^{* * *}(0.35) & 3.45^{* * *}(0.36) & 4.08^{* * *}(0.36) & 3.56^{* * *}(0.37) \\ \text { has DC pension only } & 2.25^{* * *}(0.29) & 2.10^{* * *}(0.28) & 2.21^{* * *}(0.28) & 2.09 \\ \text { has DB \& DC pension } & 4.38^{* * *}(0.38) & 3.85^{* * *}(0.40) & 4.43^{* * *}(0.39) & 3.96^{* * *}(0.40)\end{array}$

Regression also includes:

$\begin{array}{lcccc}\text { age } & \text { yes } & \text { yes } & \text { yes } & \text { yes } \\ \text { job variables } & \text { no } & \text { yes } & \text { no } & \text { yes } \\ \text { year effects } & \text { no } & \text { no } & \text { yes } & \text { yes } \\ \text { year*job variables } & \text { no } & \text { no } & \text { no } & \text { yes }\end{array}$

Data source: Survey of Consumer Finances 1983, 89, 92, 95, 98.

Sample: Full-time employees, excluding those who report tenure in excess of potential experience plus two (about 1.5\% of the sample); those whose pension type is unknown (approximately $0.5 \%$ of the remaining sample); and those with earnings in the top or bottom $1 \%$ of the distribution.

Details: The coefficient estimates and Huber-White standard errors are computed from regressions run on multiple implicates, as in Rubin (1987). The regressions were weighted using survey weights. ${ }^{*}$ indicates a confidence level of at least $90 \%,{ }^{* *} 95 \%,{ }^{* * *} 99 \%$.

Specifications: (1) and (5) includes real weekly earnings (in 1998 dollars), age and age squared. (2) and (6) add job variables (4 education, 6 industry, 6 occupation, and 6 firm size dummies, industry* occupation, education*occupation, union coverage). (3) and (7) add year dummies. (4) and (8) add variables from (2) and (3) along with year*industry, year*occupation, year*education, year*union coverage. 
Table 4: Job tenure and DB pension characteristics (OLS regression results, SCF)

Dependent variable: years of current job tenure

Men (mean of dependent variable $=8.77$ )

(1a)

(4a)

(1b)

(4b)

Independent variables:

has DB pension only

has DC pension only

has DB \& DC pension

$\begin{array}{llll}2.41^{* * *}(0.36) & 1.34^{* * *}(0.47) & 3.31^{* * *}(0.34) & 2.72^{* * *}(0.46) \\ 2.69^{* * *}(0.27) & 2.48^{* * *}(0.28) & 2.64^{* * *}(0.28) & 2.36^{* * *}(0.28) \\ 2.49^{* * *}(0.44) & 1.84^{* * *}(0.52) & 3.40^{* * *}(0.42) & 3.24^{* * *}(0.52)\end{array}$

DB pension benefits at retirement (natural log of real present value, 1998 dollars):

Individual-reported

Average

\begin{tabular}{|c|c|c|c|c|}
\hline log value of monthly benefit & $0.52^{* * *}(0.06)$ & $0.52^{* * *}(0.08)$ & $0.35^{* * *}(0.05)$ & $0.26^{* * *}(0.08)$ \\
\hline log value of lump-sum benefit & $0.38^{* * *}(0.13)$ & $0.41^{* * *}(0.12)$ & $0.29^{* * *}(0.13)$ & $0.27^{* * *}(0.12)$ \\
\hline log value of pension wealth & $0.54^{* * *}(0.05)$ & $0.52^{* * *}(0.05)$ & $0.43^{* * *}(0.05)$ & $0.41^{* * *}(0.05)$ \\
\hline g weekly earnings & $1.46^{* * *}(0.27)$ & $2.39^{* * *}(0.28)$ & $1.51^{* * *}(0.27)$ & $2.45^{* * *}(0.28)$ \\
\hline & \multicolumn{4}{|c|}{ Women $($ mean of dependent variable $=7.62$ ) } \\
\hline & \multicolumn{2}{|l|}{$(5 a)$} & (5b) & \multirow[t]{2}{*}{$(8 b)$} \\
\hline & & & & \\
\hline $\mathrm{DCl}$ & $1.24^{*}(0.73)$ & $(0.83)$ & $2.12^{* * *}(0.47)$ & $1.72^{* * *}(0.55)$ \\
\hline si & $2.39^{* * *}(0.27)$ & $2.29^{* * *}(0.26)$ & $2.35^{* * *}(0.28)$ & $2.21^{* * *}(0.27)$ \\
\hline $\mathrm{DC}$ & $1.57^{* * *}(0.63)$ & $(0.76)$ & $3.47^{* * *}(0.46)$ & $2.10^{* * *}(0.56)$ \\
\hline
\end{tabular}

DB pension benefits at retirement (natural log of real present value, 1998 dollars): Individual-reported

Average

$\begin{array}{lllllll}\log \text { value of monthly benefit } & 0.57^{* * *}(0.12) & 0.60^{* * *}(0.16) & 0.39^{* * *}(0.08) & 0.37^{* * *}(0.10) \\ \log \text { value of lump-sum benefit } & 0.15^{* * *}(0.13) & 0.19^{* * *}(0.15) & 0.06^{* * *}(0.12) & 0.06^{* *}(0.13) \\ \log \text { value of pension wealth } & 0.33^{* * *}(0.08) & 0.31^{* * *}(0.08) & 0.22^{* * *}(0.07) & 0.21^{* * *}(0.07) \\ \log \text { weekly earnings } & 1.86^{* * *}(0.75) & 2.59^{* * *}(0.35) & 1.94^{* * *}(0.31) & 2.65^{* * *}(0.36)\end{array}$

Regression also includes:

$\begin{array}{lcccc}\text { age } & \text { yes } & \text { yes } & \text { yes } & \text { yes } \\ \text { job variables } & \text { no } & \text { yes } & \text { no } & \text { yes } \\ \text { year effects } & \text { no } & \text { yes } & \text { no } & \text { yes } \\ \text { year*job variables } & \text { no } & \text { yes } & \text { no } & \text { yes }\end{array}$

Details: These regressions replicate those appearing in Table 3, with the addition of variables representing DB pension benefits expected at retirement The value was reported in one of three different ways: (1) over 95\% of individuals with a DB pension in 1989-98 reported a periodic amount that they expect to receive when they leave their job; (2) about 2.5\% of individuals with a DB pension in 1989-98 reported a lump-sum amount which they expect to receive; (3) the SCF reported expected pension wealth for 55\% of individuals with a DB pension in 1983 , based on information collected from employers. We included the natural log of the present value of each of these variables, along with dummy variables indicating which of the three variables (if any) was reported for a given observation. In regressions (1a), (4a), (5a), and (8a), the self-reported variable is included. In regressions (1b), (4b), (5b), and (8b), the average value is included, imputed on the basis of log earnings, industry, occupation, education, unionization, and employer size, separately for men and women.

The numbering of the regressions parallels the numbering in Table 3. Huber-White standard errors appear in parentheses; ${ }^{*}$ indicates a confidence level of at least $90 \%,{ }^{* *} 95 \%,{ }^{* * *} 99 \%$.

For additional information, see notes to Table 3. 
Table 5: Changes in the value of DB pensions (OLS regression results, SCF)

Dependent variable: expected monthly pension benefit (1998 dollars)

Men (mean of dependent variable $=1474$ )

(1)

Independent variables:

year dummy, 1992

year dummy, 1995

year dummy, 1998

$\begin{array}{rrrr}-8 & (170) & -46 & (187) \\ -120 & (141) & -226 & (158) \\ -174 & (164) & -295^{*} & (172)\end{array}$

Women $($ mean of dependent variable $=944)$

(3)

(4)

Independent variables:

has DB pension only

has DC pension only

has DB \& DC pension

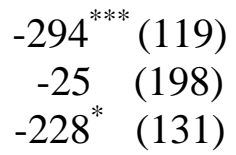

$-322^{* * *}(138)$

$-66 \quad(223)$

$-258^{* *}(124)$

Regression also includes:

age, tenure, experience

job variables

yes

yes

no yes

Data source: Survey of Consumer Finances 1989, 92, 95, 98.

Sample: Full-time employees with DB pensions who report their expected monthly benefit, excluding those who report tenure in excess of potential experience plus two (about $1.5 \%$ of full-time employees); those whose pension type is unknown (approximately $0.5 \%$ of the remaining sample); those with earnings in the top or bottom $1 \%$ of the distribution; those who report that they will receive a lump-sum benefit (2.5\% of the remaining sample) and those who do not report a benefit (2.5\% of the remaining sample). Details: The coefficient estimates and Huber-White standard errors are computed from regressions run on multiple implicates, as in Rubin (1987). The regressions were weighted using survey weights. ${ }^{*}$ indicates a confidence level of at least $90 \%,{ }^{* *} 95 \%,{ }^{* * *} 99 \%$.

Specifications: (1) and (3) includes real weekly earnings (in 1998 dollars), age and age squared, potential experience and experience squared, current tenure (linear through quartic terms), and expected future tenure (linear through quartic terms). (2) and (4) add job variables (4 education, 6 industry, 6 occupation, and 6 firm size dummies, industry* occupation, education*occupation, union coverage). 
Table 6: The earnings premium associated with job tenure

\begin{tabular}{|c|c|c|c|c|c|c|}
\hline & \multicolumn{6}{|c|}{ Men } \\
\hline & 1983 & 1987 & 1991 & 1996 & 1998 & 2000 \\
\hline \multicolumn{7}{|c|}{ Years of tenure } \\
\hline 5 & $12.9 \% * * *$ & $17.8 * * *$ & $16.8 * * *$ & 13.6 *** & $6.6 * * *$ & $11.1 * * *$ \\
\hline 10 & $20.4 * * *$ & $26.1 * * *$ & $24.7 * * *$ & $21.7 * * *$ & 15.2 *** & $16.5 * * *$ \\
\hline 15 & $24.4 \quad * *$ & $29.8 * * *$ & $29.0 * *$ & 26.6 *** & $22.6 * * *$ & $20.3 * * *$ \\
\hline 20 & 26.3 & $32.3^{* *}$ & $32.4 *$ & $30.0 *$ & 27.2 & $24.3 * *$ \\
\hline \multirow[t]{2}{*}{25} & 28.0 & 35.0 & 35.4 & 33.4 & 28.9 & 27.6 \\
\hline & \multicolumn{6}{|c|}{ Women } \\
\hline \multicolumn{7}{|c|}{ Years of tenure } \\
\hline 5 & $18.7 * * *$ & $20.6 * * *$ & $19.0 * * *$ & $20.1 * * *$ & $9.8 * * *$ & $8.8 * * *$ \\
\hline 10 & $25.5 * * *$ & $30.6 * * *$ & $26.8 * * *$ & $28.5 * * *$ & $19.8 * * *$ & $14.6 * * *$ \\
\hline 15 & $29.2 * * *$ & $35.2^{*}$ & $31.6 * * *$ & $33.0 * * *$ & $28.4 * * *$ & 18.3 ** \\
\hline 20 & $34.4 * * *$ & 37.9 & $37.3 * * *$ & $38.1 * * *$ & 34.2 & 20.9 \\
\hline 25 & 41.4 & 39.9 & 44.3 & 45.1 & 36.1 & 23.4 \\
\hline
\end{tabular}

Data source: Outgoing rotation groups of the Current Population Survey tenure supplements of January 1983, 1987, 1991 and February 1996, 1998, and 2000.

Sample: Employees aged 21-59 who were working or had a job but were not at work, excluding those who report earnings in the top or bottom $1 \%$ of the distribution. The sample size is 32,806 men and 31,124 women.

Details: Each cell in this table reports the estimated effect of years of job tenure on the natural log of the real wage, expressed as a percentage increase associated with a given number of years of tenure. These estimates are obtained from regressions run separately on men and women. The regressions include years of job tenure (with nonlinear terms included up to the fourth power), all interacted with the CPS year; years of potential experience (up to the fourth power), all interacted with the CPS year; a dummy for being a usual full-time worker; dummies for four education categories, all interacted with the CPS year; 51 industry dummies, interacted with a dummy for being in the public sector; and 45 occupation dummies, interacted with a dummy for being in the public sector. The real wage is defined as weekly earnings divided by usual weekly hours.

All of the estimated earnings premia are significantly different from zero. The asterisks next to each cell indicate the significance level on an F-test that compares the earnings premium with the one reported in the cell below. ${ }^{*}$ indicates a confidence level on the F-statistics of at least $90 \%,{ }^{* *} 95 \%,{ }^{* * *} 99 \%$. These tests are based on Huber-White standard errors. Weighted using the outgoing rotation group weights. 


\section{Table 7: Technological change and long-term jobs (OLS regression results, April 1993 CPS)}

\begin{tabular}{|c|c|c|c|c|c|c|}
\hline \multirow{4}{*}{$\begin{array}{l}\text { Independent variables } \\
\text { (averages, by industry): } \\
\text { computer use, } 1993\end{array}$} & \multicolumn{6}{|c|}{ Dependent variable (averages, by industry): } \\
\hline & \multicolumn{3}{|c|}{ \% with a DB pension } & \multicolumn{3}{|c|}{ Average job tenure } \\
\hline & $(1)$ & $(2)$ & (3) & (6) & $(7)$ & $(8)$ \\
\hline & $\begin{array}{l}-0.095 \\
(0.080)\end{array}$ & $\begin{array}{l}-0.183 \\
(0.113)\end{array}$ & $\begin{array}{l}-0.200 * \\
(0.119)\end{array}$ & $\begin{array}{l}-4.00 * * * \\
(1.25)\end{array}$ & $\begin{array}{l}-3.99 * * \\
(1.78)\end{array}$ & $\begin{array}{l}-4.02 * * * \\
(1.87)\end{array}$ \\
\hline \multicolumn{7}{|c|}{ past changes in computer use: } \\
\hline $1984-89$ & - & $\begin{array}{c}0.370 \\
(0.332)\end{array}$ & $\begin{array}{c}0.436 \\
(0.358)\end{array}$ & - & $\begin{array}{l}-0.09 \\
(5.23)\end{array}$ & $\begin{array}{c}0.40 \\
(5.66)\end{array}$ \\
\hline 1989-93 & - & $\begin{array}{c}0.041 \\
(0.557)\end{array}$ & $\begin{array}{c}0.034 \\
(0.562)\end{array}$ & - & $\begin{array}{c}0.13 \\
(8.77)\end{array}$ & $\begin{array}{c}0.11 \\
(8.88)\end{array}$ \\
\hline \multicolumn{7}{|c|}{ future changes in computer use: } \\
\hline $1997-93$ & - & - & $\begin{array}{l}-0.185 \\
(0.387)\end{array}$ & - & - & $\begin{array}{l}-0.41 \\
(6.19)\end{array}$ \\
\hline $\begin{array}{l}\text { Independent variables } \\
\text { (averages over past } 10 \\
\text { years, by industry) }\end{array}$ & (4) & & (5) & (9) & & $(10)$ \\
\hline TFP growth & $\begin{array}{l}-3.41 \\
(1.22\end{array}$ & & $\begin{array}{l}-3.43 * * * \\
(1.23)\end{array}$ & $\begin{array}{r}20.7 \\
(22.7\end{array}$ & & $\begin{array}{c}19.7 \\
(22.9)\end{array}$ \\
\hline level of investment $/ 10^{6}$ & $\begin{array}{l}-0.50 \\
(0.22\end{array}$ & & - & $\begin{array}{l}-6.9 \\
(4.12\end{array}$ & & - \\
\hline capital stock $/ 10^{6}$ & - & & $\begin{array}{l}-0.24 * * \\
(0.10)\end{array}$ & - & & $\begin{array}{l}-3.46 * \\
(2.02)\end{array}$ \\
\hline
\end{tabular}

Data source: Current Population Survey, tenure and compensation data from April 1993; computer use data from October 1984, 1989, 1993, and 1997. Jorgenson Total Factor Productivity Series, 1958-1996, obtained at http://post.economics.harvard.edu/faculty/jorgenson/data/35klem.html (Jorgenson, Gollop, and Fraumeni 1987).

Sample: The underlying samples from the CPS consist of workers aged 18-64 who are not self-employed. For the computer use data, sample sizes range from 49,601-54,647. For the April 1993 CPS data, the sample is restricted further to those who know their pension status, and the sample size is 12,951. Both data sets are then collapsed by taking averages within each of 50 industries, using the appropriate CPS sampling weight.

Details: Each numbered column reports coefficient estimates, standard errors in parentheses, and the significance level $\left({ }^{*} 90 \%,{ }^{* *} 95 \%,{ }^{* * *} 99 \%\right)$ from an OLS regression where the dependent variable is defined at the top of the column, some of the independent variables are reported in the rows, and the other independent variables are log weekly wages and a dummy for whether the employer offers health insurance. Each regression is weighted using the number of people in the industry in the April 1993 CPS. Capital and investment are deflated to 1992 dollars. 


\section{Table 8: Technological change and long-term jobs (OLS regression results, multiple CPS tenure supplements)}

\begin{tabular}{|c|c|c|c|c|c|c|}
\hline \multirow{3}{*}{$\begin{array}{l}\text { Independent variables } \\
\text { (averages, by industry): } \\
\text { computer use }\end{array}$} & \multicolumn{6}{|c|}{$\begin{array}{c}\text { Dependent variable (averages, by industry): } \\
\text { Average job tenure }\end{array}$} \\
\hline & $(1)$ & $(2)$ & (3) & $(4)$ & $(5)$ & (6) \\
\hline & $\begin{array}{l}-1.09 * * \\
(0.48)\end{array}$ & $\begin{array}{l}-0.77 \\
(0.56)\end{array}$ & $\begin{array}{l}-1.04 * * \\
(0.48)\end{array}$ & $\begin{array}{l}-0.67 \\
(0.61)\end{array}$ & $\begin{array}{l}-0.58 \\
(1.11)\end{array}$ & $\begin{array}{l}-1.10 * \\
(0.67)\end{array}$ \\
\hline $\begin{array}{l}\text { past change in } \\
\text { computer use }\end{array}$ & - & - & $\begin{array}{c}0.91 \\
(1.14)\end{array}$ & $\begin{array}{l}-0.80 \\
(1.89)\end{array}$ & - & - \\
\hline Includes year dummies & & $\mathrm{X}$ & & $\mathrm{X}$ & $\mathrm{X}$ & $\mathrm{X}$ \\
\hline Sample & & $1983,87,9$ & $1,96,98,0$ & & $<1990$ & $>1990$ \\
\hline $\begin{array}{l}\text { Independent variables } \\
\text { (averages over past } 10 \\
\text { years, by industry) }\end{array}$ & $(7)$ & $(8)$ & $(9)$ & $(10)$ & $(11)$ & $(12)$ \\
\hline TFP growth & $\begin{array}{c}9.0 \\
(10.9)\end{array}$ & $\begin{array}{l}14.5 \\
(11.4)\end{array}$ & $\begin{array}{c}7.6 \\
(10.8)\end{array}$ & $\begin{array}{c}12.7 \\
(11.4)\end{array}$ & $\begin{array}{c}28.9 * * \\
(16.1)\end{array}$ & $\begin{array}{c}-0.3 \\
(16.6)\end{array}$ \\
\hline level of investment $/ 10^{6}$ & $\begin{array}{l}-8.6^{* * *} \\
(2.6)\end{array}$ & $\begin{array}{l}-7.4 * * * \\
(2.7)\end{array}$ & - & - & $\begin{array}{l}-4.8 \\
(4.7)\end{array}$ & $\begin{array}{l}-9.2 * * * \\
(3.4)\end{array}$ \\
\hline capital stock $/ 10^{6}$ & - & - & $\begin{array}{l}-4.6^{* * *} \\
(1.3)\end{array}$ & $\begin{array}{l}-4.0 * * * \\
(1.3)\end{array}$ & - & - \\
\hline Includes year dummies & & $\mathrm{X}$ & & $\mathrm{X}$ & $\mathrm{X}$ & $X$ \\
\hline Sample & & 1983, 8 & 7, 91, 96 & & $<1990$ & $>1990$ \\
\hline
\end{tabular}

Data source: Current Population Survey, tenure and compensation data from January 1983, 1987, and 1991 and February 1996, 1998, and 2000; computer use data from October 1984, 1989, 1993, and 1997. Jorgenson Total Factor Productivity Series, 1958-1996, obtained at http://post.economics.harvard.edu/ faculty/jorgenson/data/35klem.html (Jorgenson, Gollop, and Fraumeni 1987).

Sample: The underlying samples from the CPS consist of workers aged 18-64 who are not self-employed. For the computer use data, sample sizes range from 49,601-54,647. For the tenure data, sample sizes range from 13,389-56,401. Both data sets are then collapsed by taking averages within each of 50 industries, using the appropriate CPS sampling weight.

Details: Each numbered column reports coefficient estimates, standard errors in parentheses, and the significance level $\left({ }^{*} 90 \%,{ }^{* *} 95 \%,{ }^{* * *} 99 \%\right.$ ) from an OLS regression where the dependent variable is average job tenure, some of the independent variables are reported in the rows, and the other independent variable is log weekly wages. Computer use data in a given year are constructed as linear combinations of the averages from the computer use supplements immediately preceding and following that year, where the weights depend on the number of years. Each regression is weighted using the number of people in the industry in that year. Capital and investment are deflated to 1992 dollars. 
Figure 1: Accrual of Pension Wealth

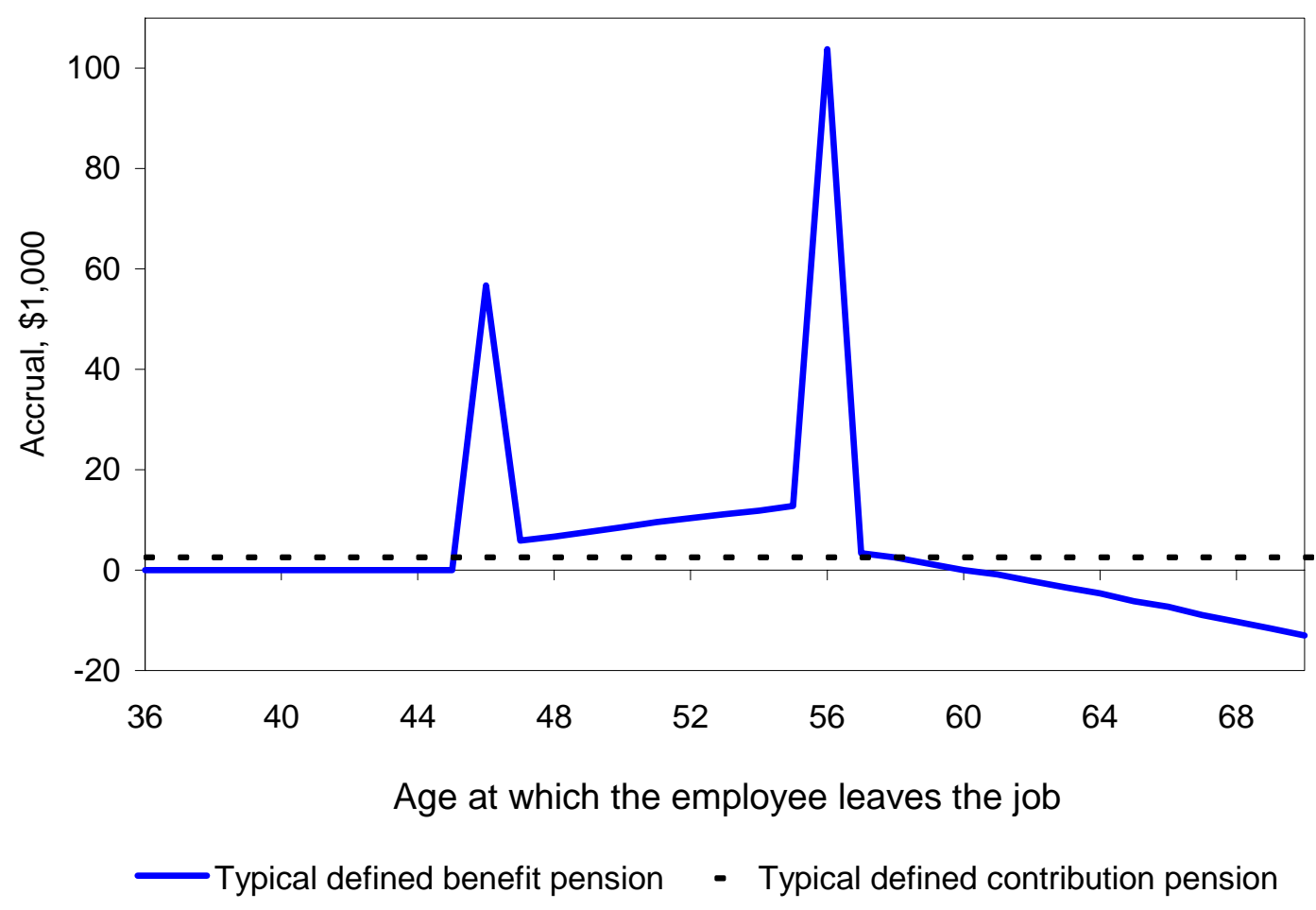

Figure 2

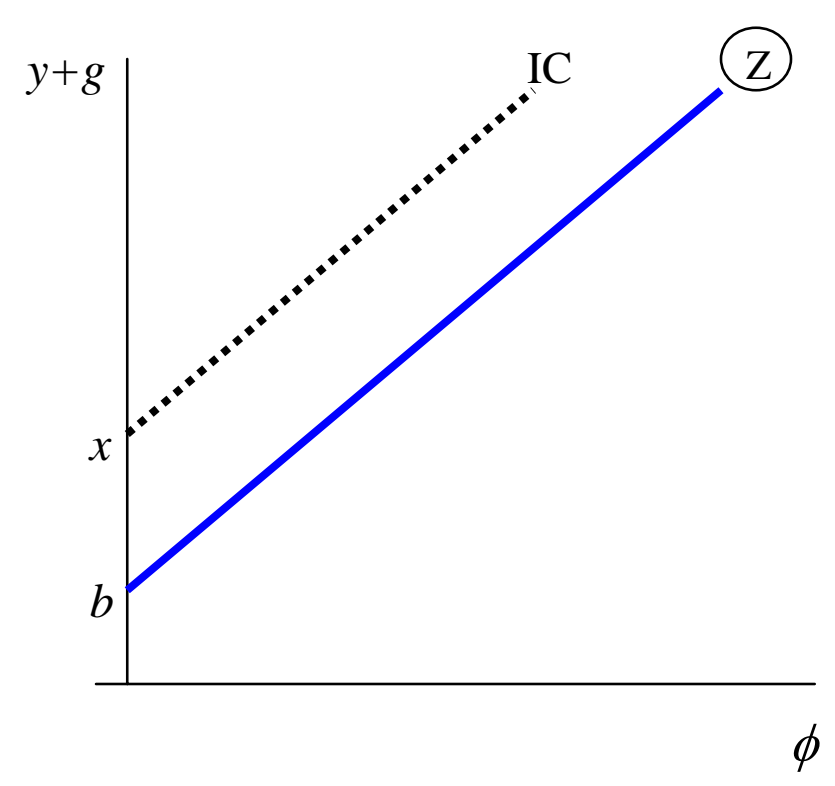




\section{Figure 3}

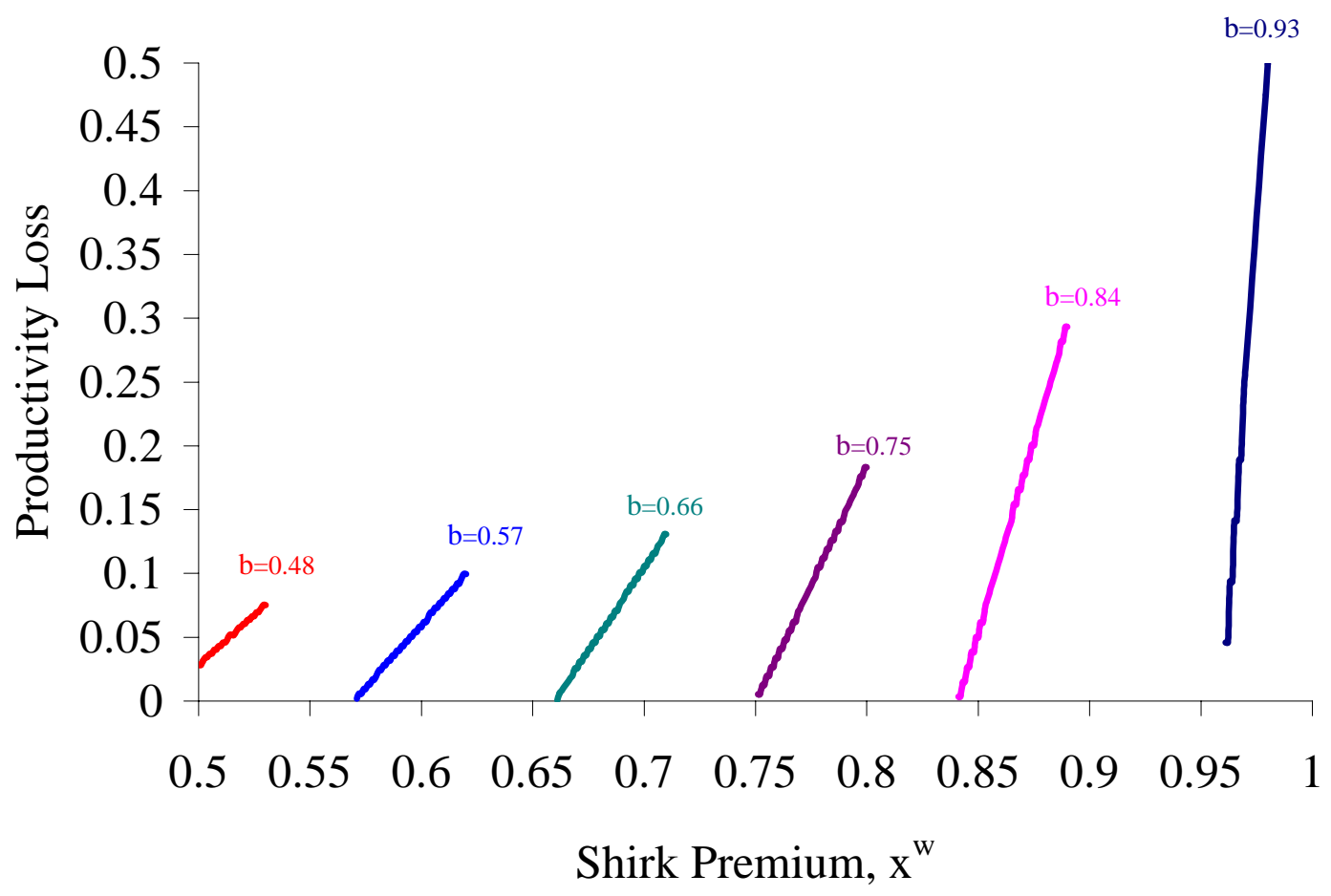

Figure 4

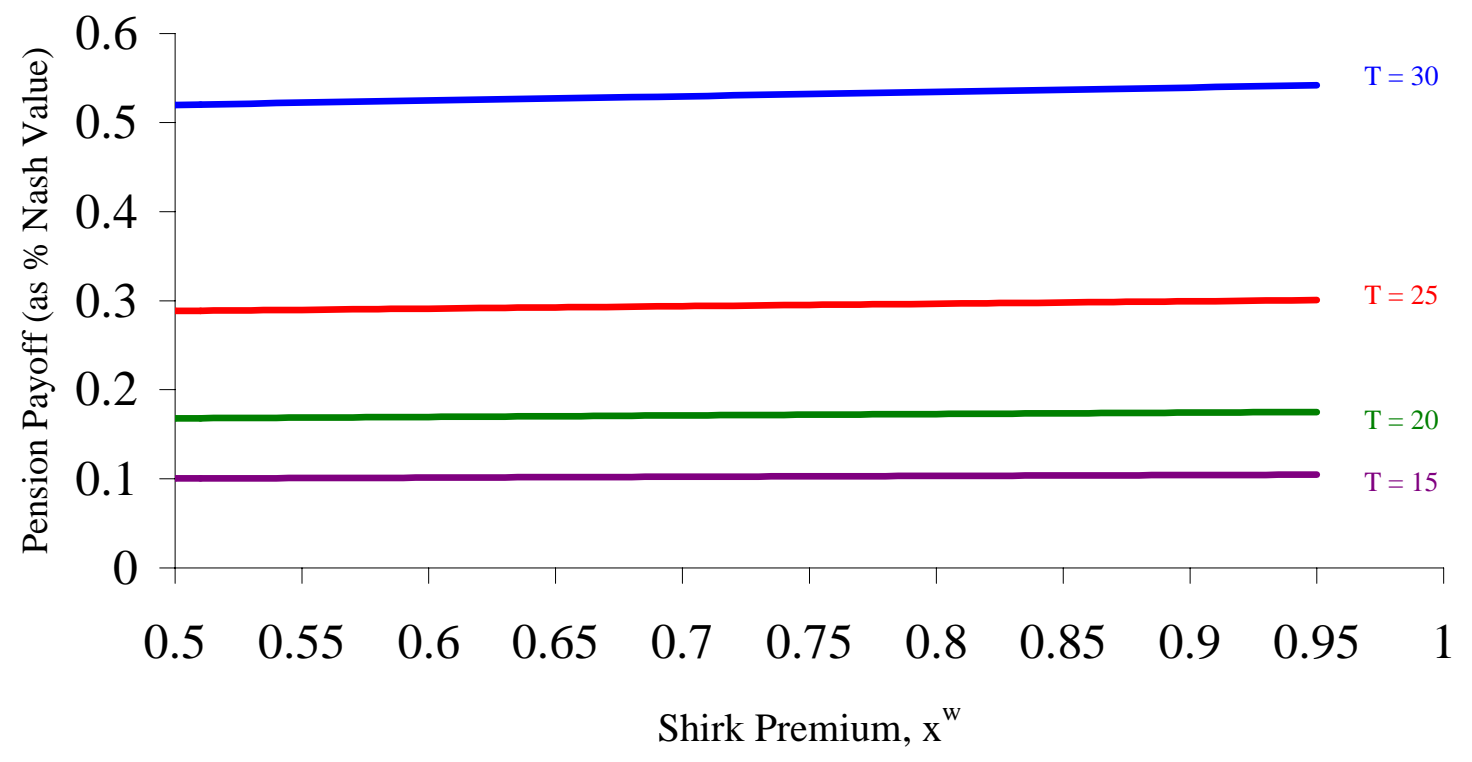

